\title{
ROS Homeostasis in Abiotic Stress Tolerance in Plants
}

\author{
Kalaivani K. Nadarajah 1 \\ Department of Biological Sciences and Biotechnology, Faculty of Science and Technology, \\ Universiti Kebangsaan Malaysia, 43600 UKM BANGI, Malaysia; vani@ukm.edu.my
}

Received: 4 June 2020; Accepted: 26 June 2020; Published: 23 July 2020

\begin{abstract}
Climate change-induced abiotic stress results in crop yield and production losses. These stresses result in changes at the physiological and molecular level that affect the development and growth of the plant. Reactive oxygen species (ROS) is formed at high levels due to abiotic stress within different organelles, leading to cellular damage. Plants have evolved mechanisms to control the production and scavenging of ROS through enzymatic and non-enzymatic antioxidative processes. However, ROS has a dual function in abiotic stresses where, at high levels, they are toxic to cells while the same molecule can function as a signal transducer that activates a local and systemic plant defense response against stress. The effects, perception, signaling, and activation of ROS and their antioxidative responses are elaborated in this review. This review aims to provide a purview of processes involved in ROS homeostasis in plants and to identify genes that are triggered in response to abiotic-induced oxidative stress. This review articulates the importance of these genes and pathways in understanding the mechanism of resistance in plants and the importance of this information in breeding and genetically developing crops for resistance against abiotic stress in plants.
\end{abstract}

Keywords: antioxidative; enzymatic and non-enzymatic enzymes; ROS reactive genes; hormones; signaling; environmental stresses

\section{Introduction}

Abiotic stresses affect plant morphology, biochemistry, physiology, and anatomy through processes such as photosynthesis, respiration, growth, and development, where prolonged stress induces death [1-3]. Plants have evolved physiological and metabolic mechanisms that may be instrumental in alleviating environmental stresses such as drought, cold, salinity, metal toxicity, and submergence. These processes are regulated through the activation of gene networks or pathways that result in either enhanced tolerance or resistance [3-5]. During stress, harmful by-products that are detrimental to plants are produced. Superoxide radicals, hydrogen peroxide $\left(\mathrm{H}_{2} \mathrm{O}_{2}\right)$, hydroxyl radicals $\left(\mathrm{OH}^{\bullet}\right)$, and singlet oxygen $\left({ }^{1} \mathrm{O}_{2}\right)$ are reactive oxygen species (ROS) formed in response to the reduction of oxygen molecules in planta [5]. These oxygen radicals affect proteins and lipids, resulting in cellular damage and death [6]. When provided with optimal growth conditions, the ROS levels within organelles are low. However, in periods of stress, these levels are elevated due to disturbances in cellular water potential, affecting cellular homeostasis [7-9]. Homeostasis of ROS in the cell is achieved through a balance between its production and scavenging [9], where growth conditions, severity, and duration of stress affects cellular equilibrium $[10,11]$. ROS production and scavenging are somewhat opposed, where an overproduction of this molecule is toxic to the cell, while, as a signal transducer, it triggers the plant's defense. The initial burst of ROS production activates downstream processes post-stress, which leads to defense mechanism mobilization and the management of stress [12-14]. The ROS-scavenging mechanism plays a crucial role in protecting against stress damage in plants $[7,14,15]$. Understanding 
the mechanism of ROS production, signaling, and scavenging allows for a powerful strategy to enhance crop tolerance toward environmental conditions [16].

ROS is generated in the cell as a consequence of electron leakage during photosynthesis and respiration [17]. To moderate the overproduction of ROS and oxidative stress, plants have a well-regulated antioxidative mechanism that consists of enzymatic and non-enzymatic components that can balance ROS synthesis and scavenging and prevent cellular damage [18-20]. Superoxide dismutase (SOD), catalase (CAT), and peroxides (POX) are among the enzymatic antioxidant systems that regulate the homeostasis of ROS within organisms [21]. These enzymes are involved in the reduction process of $\mathrm{O}^{2-}$ to $\mathrm{H}_{2} \mathrm{O}_{2}$ [22]. The non-enzymatic components, which are generally made up of players such as ascorbic acids, $\alpha$-tocopherol, flavanoid, glutathione, carotenoids, lipids, and phenolic compounds, efficiently mitigate oxidative damage by reducing ROS activity or by working together with the enzymatic players to achieve efficient antioxidant activity via the utilization of $\mathrm{H}_{2} \mathrm{O}_{2}[19,20]$. The mode of action and regulation of both these antioxidant systems and the members will be discussed later.

In the past years, the importance of oxidative stress management and the role of local and systemic ROS signaling in addressing abiotic stress have been extensively studied $[15,23]$. Despite these studies, there remains a wide variation in the reports on antioxidant activities in various abiotic-stressed plants. Here, we provide an overview of the antioxidant stress management mechanisms in plants and the role they play in abiotic stress response. The regulation and key components of abiotic stress management are yet to be completely understood. This review provides an overview of the status of ROS production in plants and how the plant system achieves ROS homeostasis. Further, the signaling involved in achieving homeostasis between ROS production and scavenging within plant organelles is discussed in brief. Most importantly, this review provides a list of genes involved in ROS regulation in abiotic stress. This information is important for us to identify pathways and genes that regulate oxidative stress in plants and to determine key targets for use in the breeding and genetic engineering of crops.

\section{Antioxidants and Abiotic Stress Modulation}

The whole plant experiences abiotic stress. The stress experienced is then transmitted to distal tissues in the plant through signaling systems that involve hormones or molecules (abscisic acid (ABA), jasmonate salicylic acid, etc.). This, therefore, indicates the importance of stress management in mitigating the effects of stress on the whole plant [24-26]. Reviews have focused on ROS metabolism, ROS sensory response, signaling networks [13,27-29], and their ability to cross-talk with other molecules in addressing developmental and environmental stresses [27,30,31]. Most reviews highlight the control over stomatal aperture, reduced $\mathrm{CO}_{2}$ levels, and photosynthesis as the contributing factor toward elevated ROS levels in plants [17,32-35]. Elevated levels of abiotic stress-induced ROS may be produced through a reduction in electron transport in the Calvin cycle and a higher electron leakage during photosynthesis in the Mehler reaction. Together, this results in higher respiration and lower photosynthesis and elevated ROS levels in stressed tissues [36]. Both these reactions occur within the chloroplast and, therefore, require these organelles to be robust against ROS, which is achieved through the function of antioxidant enzymes (enzymatic regulators) that quenches ROS activity. In addition, abiotic stresses (salt, heat, and drought) also influence photo-respiration, resulting in hydrogen peroxide $\left(\mathrm{H}_{2} \mathrm{O}_{2}\right)$ production [17]. Within plant cells, both $\mathrm{H}_{2} \mathrm{O}_{2}$ and $\mathrm{O}^{2-}$ function as secondary messengers that control cell death, cell cycle, growth, development, hormone signaling, and stress responses [37]. However, the scavenging systems are not reactive toward hydroxyl radicals and, at high levels, result in deleterious effects to organelles $[32,36,38]$ through lipid peroxidation, which injures membranes and causes damage to biological molecules such as lipids, nucleic acids, and proteins, ultimately resulting in cellular damage and death [39].

Crop production is severely impaired as a consequence of overproduction of ROS in the organs during abiotic stresses [21]. In response to endogenous signals (hormones and signal molecules) and exogenous environmental stimuli (biotic or abiotic stresses), several enzymes such as NADPH oxidases, 
amine oxidases, polyamine oxidases, oxalate oxidases, and a large family of class III peroxidases that are localized at the cell surface or apoplast are induced and result in elevated ROS production $[21,40,41]$. Therefore, to reduce loss from ROS, the antioxidant activity in the plant needs to increase [42]. As ROS is continuously produced in plants within the chloroplast, peroxisome, and mitochondria, ROS removal systems have to be well-controlled to ensure the wellbeing of tissues and organs. Resistant lines exhibit better ROS removal systems and membrane stability toward deleterious radicals compared to susceptible ones [28,43]. It is, therefore, important for the homeostasis of ROS scavenging to be maintained in all stress induced (biotic or abiotic) and normal physiological responses in planta $[18,44]$.

\section{Multi-facetted Mechanisms in Abiotic Stress-Related ROS Homeostasis}

In unstressed conditions, ROS is generated within the cell at low levels. However, when subjected to abiotic stresses, ROS levels are elevated, which activates stress pathways within the plant cells [27,45]. Therefore, it is essential that the various enzymatic and non-enzymatic ROS-scavenging systems present in different organelles work together in ROS detox and achieve ROS homeostasis [46,47]. Ford et al. (2011), in a proteomic study conducted on wheat, showed that several antioxidative enzymes were present under stress [48]. The most dominant enzyme was catalase (CAT), which is required for metabolizing photorespiratory $\mathrm{H}_{2} \mathrm{O}_{2}$ when water is limited like in drought. Similar antioxidative systems were also present in Arabidopsis thaliana [49] where core genes for redox homeostasis include antioxidative and reductant-regenerating enzymes, which respond in both a complex and specific manner. These genes that regulate enzymatic and non-enzymatic processes work in tandem within the system. As many genes are induced during ROS response, an equal number are repressed during the same process [50-52].

Besides the enzymatic and non-enzymatic processes, sugars are the new emerging ROS scavengers. The emerging "sugar as antioxidant" concept is based on redox balance that is achieved through their relationship in photosynthesis, mitochondrial respiration, and fatty acid $\beta$-oxidation in various organelles. Excess sugar results in increased cytosolic $\mathrm{H}_{2} \mathrm{O}_{2}$ through metabolic pathways while sugars also result in the reduction in power that contribute toward $\mathrm{H}_{2} \mathrm{O}_{2}$ scavenging via the oxidative pentose phosphate (OPP) pathway, which feeds the NADPH metabolism that activates the antioxidative process $[53,54]$. This is the dual nature of sugars in ROS homeostasis. Sugars like mannitol can protect from the oxidative damage of chloroplasts. These sugars affect gene expression through sugar-specific signaling cascades, which regulate the expression of abiotic stress-related genes such as superoxide oxidase (SOD), heat shock proteins (HSP) and glutathione-S-transferases (GST). In recent years, hexokinase (HXK), Snf1-related kinase 1, and INV have been identified as sugar signaling regulators. Trehalose is another sugar that has been shown to regulate abscisic acid (ABA) metabolism and protect against oxidative stress of photosystem II (PSII) during stress in plants $[55,56]$. These sugar-specific pathways together with plant hormone signaling and stress-related pathways, when integrated, are able to participate in plant defense responses.

Reports have also implicated proline in maintaining redox homeostasis by resulting in NADPH utilization. In a study involving transgenic wheat, higher proline resulted in reduced lipid peroxidation and ROS damage during abiotic stresses [57]. Proline mitigates stress through up-regulation of proline biosynthesis, scavenging of $\mathrm{OH}^{\bullet}$ or ${ }^{1} \mathrm{O}_{2}$, and an active proline metabolic flux linked to other metabolic pathways. Through this, proline maintains cellular energy and $\mathrm{NADP}^{+} / \mathrm{NADPH}$ balance. This protects cells and contributes toward other pathways such as the tricarboxylic acid cycle (TCA) and GSH. Proline feeds into the electron transport chain (ETC) via proline dehydrogenase (PRODH) that results in superoxide and $\mathrm{H}_{2} \mathrm{O}_{2}$ formation. When PRODH expression is increased due to high ROS, apoptosis and cell death results in the activation of the hypersensitive response (HR). PRODH-dependent ROS production in the mitochondria is linked to proline, pyrroline-5-carboxylate reductase (P5CR), and delta-1-pyrroline-5-carboxylate dehydrogenase (P5CDH). Therefore, an increase in $\mathrm{PRODH} / \mathrm{P5CDH}$ results in an increase in proline metabolic cycling where $\mathrm{P} 5 \mathrm{C}$ is converted to proline via P5CR and NADPH [58]. 
Sharma et al. (2011) stated that proline accumulates during drought as a solute where mutants defective in proline production were sensitive to drought. Pro-Glu is also implicated in NADP[H] homeostasis [59]. Proline and glycine betaine aids in water uptake $[60,61]$ and ROS quenching, which protects against tissue damage [62,63]. Besides scavenging hydroxyl ions, prolines also bind redox active ions and protect against hydroxyl ion damage [64]. Together with sugars, prolines protect the photosystems against peroxidation in drought [65]. Recently, ABA-insensitive mutants revealed that abi4 increased proline levels in stress and could not be rescued through exogenous application of ABA. However, when sucrose was supplied, the ABA response was restored, indicating that ABI4 has a role in ABA-sugar regulation of proline [53]. Excess ROS generation may also be circumvented through alternative oxidases that divert the electron flow and reduce electron leaks that generate $\mathrm{O}_{2}{ }^{\bullet-}[66]$. There are possibly other mechanisms utilized by plants to assist in the balancing of ROS levels and the energy spent in plants. These processes may include events such as leaf curling, leaf movement, and photosynthesis apparatus reassembly [67]. Through the change in the ROS levels, plants can perceive stress and respond accordingly through complex pathways and processes [68]. The easiest way of keeping ROS homeostasis within the plant is to remove the stress on the plant system, thus resulting in a reduction in ROS to levels non-toxic to the plant [12].

\section{Signaling and Control in Abiotic Stress-Associated ROS Homeostasis}

Plant systems activate signaling cascades that trigger downstream components to manage both biotic and abiotic stress. $\mathrm{H}_{2} \mathrm{O}_{2}$ signaling pathways result in the accumulation of protectants that guard against the effects of the cellular redox state and the effect therein. ROS participates in stress signaling through the transduction of signals from mitogen-activated protein kinases (MAPKs) $[34,69]$, which leads to the induction of several pathways, and activation of gene expression downstream. The activated MAPKs signaling cascade adjusts the levels of $\mathrm{H}_{2} \mathrm{O}_{2}$ through the detox antioxidant systems [70,71]. The $\mathrm{H}_{2} \mathrm{O}_{2}$ is the most stable and easily disseminated form of oxidative stress. These molecules act as a switch that enables the messenger to be effective. In addition, the $\mathrm{H}_{2} \mathrm{O}_{2}$ molecules have affinity to thiol groups, which implies a role for this molecule in stress modulation [40,47]. Compared to the animal system, plants have a more modulatory effect on the levels of $\mathrm{H}_{2} \mathrm{O}_{2}$ compared to completely destroying the molecule within the cell [32,47]. This is achieved through the role of antioxidants within the cell that regulates ROS signaling and levels in the host [40,72,73]. Primary or secondary messengers trigger plant-signaling cascades. Some plant hormones like auxins (IAA), abscisic acid (ABA), ethylene (ET), cytokinins (CK), brassinosteroids (BR), gibberellins (GA), jasmonates (JA), and salicylic acid (SA) regulate plant defenses and other biological processes in response to stress [73-75]. When under stress, the signal is amplified and stress-related genes are induced in response through signal molecules (ABA, SA, JA, and ET) [73,76-78].

There is an intricate connection between ROS levels and ABA produced in plants. ABA is probably the most important signal molecule that controls a lot of physiological processes including stress response to abiotic stress $[79,80]$, where it regulates osmotic balance and induces resistance to stresses [79-81]. This is achieved through the activation of antioxidant genes (CAT, SOD, peroxidase (POX)) by ABA [82] through ROS-induction and increased levels of NADPH oxidase [83]. In rice, drought-hypersensitive mutants DSM1 and DSM2 have shown the ability to regulate POX expression and control ABA levels that lead to ROS quenching [84,85]. Further, over-expressed OsCPK4 and OsSIK1 genes regulate avoidance of lipid peroxidation, and results in the accumulation of SOD, CAT, and POX that acts to lower the $\mathrm{H}_{2} \mathrm{O}_{2}$ levels in the cell [86-88]. Up-regulated levels of antioxidant genes (CAT, SOD, POX, GST) result in reduced ROS levels. Research has also shown that the induced expression of GST genes by cold, salt, drought, and heavy metals is a common mechanism for increased tolerance to oxidative damage. In alfalfa, the over-expression of the MsGSTU8 gene with higher GST activity reduces ROS accumulation by increasing other antioxidant enzyme activities to improve osmotic regulation and reduce ROS damage [89]. Through mutant studies in Arabidopsis, two PP2C phosphatases ABI1 and ABI2 were identified as negative regulators of ABA signaling, 
and down-regulators of $\mathrm{H}_{2} \mathrm{O}_{2}$ in vitro. $\mathrm{ABI} 1$ and $\mathrm{ABI} 2$ are involved in $\mathrm{Ca}^{2+}$ ion channeling through ABA signaling that controls stomatal closure. ABA-induced $\mathrm{Ca}^{2+}$ ion channels were disrupted in abi1-1 and abi2-1 mutants, where stomatal closure was affected in the abi2-1 mutant, while abi1-1 remained functional. However, in vivo, both genes interacted with GPX3 (glutathione peroxidase) and regulated ABA- and $\mathrm{H}_{2} \mathrm{O}_{2}$-induced stomatal closure. Oxidized GPX3 reduced the phosphatase activity of ABI2 and converted $\mathrm{ABI} 2$ to an oxidized form in vitro. ABI1 acts upstream of ROS production and ABI2 works downstream of ROS production in the cell [90-92]. In another set of Arabidopsis genes, AtGPX3 and AtGPX6, $\mathrm{H}_{2} \mathrm{O}_{2}$ levels affect ABA signaling, ABA-responsive gene expression, $\mathrm{CA}^{2+}$ channel activation, and stomatal closure, indicating that the redox status regulates all these processes [93-95].

\section{Organelles Regulation of ROS Homeostasis during Abiotic Stress}

In the following sections, we will review the effect of abiotic stresses on plant cells and their effects on different organelles. Figures 1-4 describe the processes ongoing in each organelle under abiotic stress.

\subsection{ROS Regulation in the Chloroplast}

Photosystems (PS) I and II are the reaction center in the chloroplast where ROS is produced through inhibition of $\mathrm{CO}_{2}$, and low water levels are due to stress. Control of ROS levels in the chloroplast is vital for plant survival under stress [96]. The ETC in the PS is the chief source of ROS in chloroplasts. The ROS status in plants changes with the physiological and environmental status of the plant. When not stressed, the electrons flow from the excited PS to reduce NADP to NADPH, which then enters the Calvin cycle where $\mathrm{CO}_{2}$ is reduced as the electron acceptor. Conversely, there is an overload on ETC, which results in electron leakage from ferredoxin to $\mathrm{O}_{2}$, producing $\mathrm{O}_{2}{ }^{\bullet-}$ [97]. When exposed to high light intensity with low $\mathrm{CO}_{2}$ intake due to stomatal closure, there is a direct transfer of electron to molecular oxygen through the Mehler reaction in PSI [38]. These superoxide radicals are converted by a membrane-bound $\mathrm{Cu} / \mathrm{ZnSOD}$ to $\mathrm{H}_{2} \mathrm{O}_{2}$, which is further converted by a thylakoid-bound POX to water [98]. The thylakoid-based POX then reacts with thioredoxin to protect against oxidative stress, especially in drought, and provides an alternate water-water cycle to detox the radicals in the chloroplast $[18,99,100]$. Meanwhile, in PSII, ${ }^{1} \mathrm{O}_{2}$ are generated through electron transfer. $\mathrm{H}_{2} \mathrm{O}_{2}$ produced in PSI plays a role in inhibiting ${ }^{1} \mathrm{O}_{2}$ through the water-water cycle [101-103]. Levels of singlet oxygen when kept unchecked trigger genetic programming such as growth retardation and death through the EXECUTER pathways [104] (Figure 1).

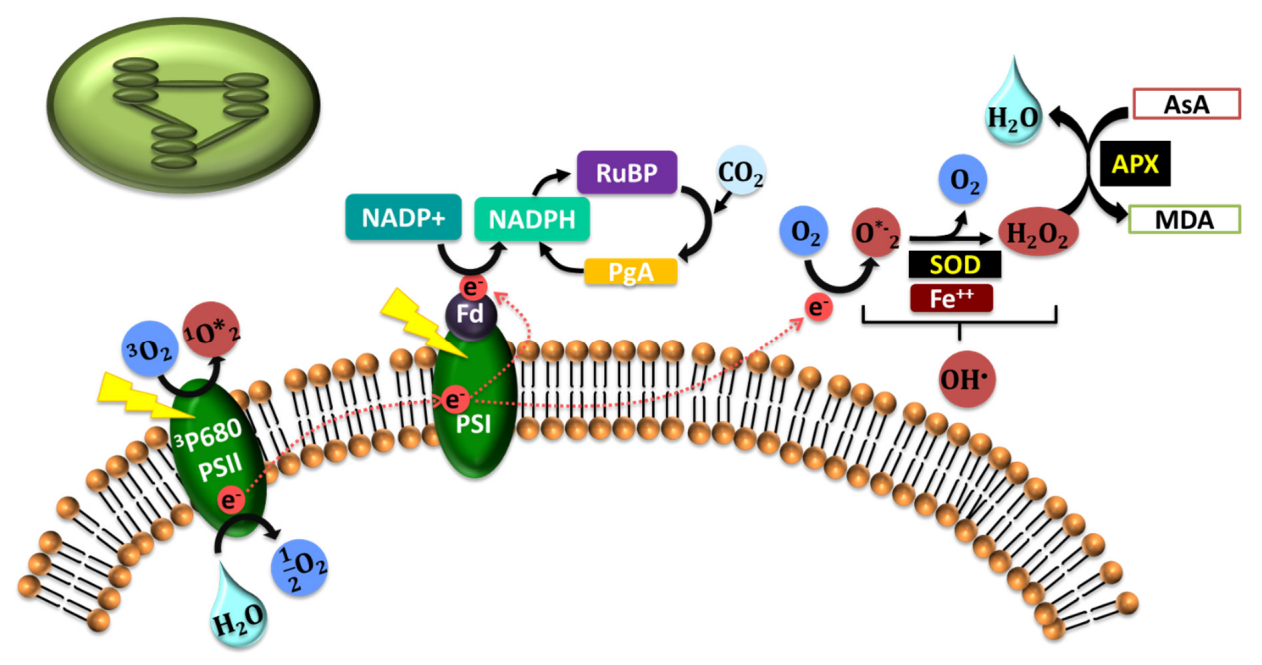

Figure 1. A diagrammatic representation of the processes in the chloroplast during stress where reactive oxygen species (ROS) is produced through inhibition of $\mathrm{CO}_{2}$, and low water levels are due to stress. The electron transport chain (ETC) in the photosystem (PS) is the main source of ROS in chloroplast. 


\subsection{ROS Regulation in the Mitochondria}

The production of ROS is lower in the mitochondria compared to the chloroplast. There is a variation in plant and animal ROS production in mitochondria, wherein in plants, the mitochondria are also the site of photorespiration that is surrounded by carbohydrate solutes [88]. In drought, when respiration rates are high, and transpiration and photosynthesis are low, the demand on mitochondrial ATP is high to compensate for chloroplast ATP production, which causes an increase in ROS levels in the mitochondria [105]. ROS is produced within several sites in mitochondria. In this organelle, the $\mathrm{O}_{2}$ is reduced to $\mathrm{O}_{2}{ }^{\bullet-}$ via the NADPH dehydrogenase [complex I] [106]. Within the mitochondria complex I and III, the electron transfer complex has sufficient energy to reduce $\mathrm{O}_{2}$ to ROS from overreduction of the ubiquinone pool (UQ) [107-110]. An electron is donated to cytochrome $C_{1}$ when UQ is in a fully reduced state. This results in a highly unstable radical complex, which brings about electron leakage and $\mathrm{O}_{2}{ }^{\bullet-}$ formation [111]. When NAD is low within the complex, there is a reverse electron flow from complex II to I $[112,113]$

There are alternative ROS-producing sources in the mitochondria like aconitase [114]. While the mitochondria are the source of ROS production, this organelle also has its detoxification system made up of alternative oxidase (AOX) and MnSOD. Aconitase causes the production of ROS while 1-galactono- $\gamma$ lactone dehydrogenase (GAL) directly donates an electron to the ETC [63]. The $\mathrm{O}_{2}{ }^{\bullet-}$ that is formed in this organelle is quickly converted to a stable membrane-permeable $\mathrm{H}_{2} \mathrm{O}_{2}$ by MnSOD or ascorbate peroxidase (APX). AOX together with MnSOD work at maintaining the reductive state of the UQ pool while reducing $\mathrm{O}_{2}{ }^{-}$to $\mathrm{O}_{2}[115,116]$. Giraud et al. (2008) report that mutant AOX Arabidopsis plants were sensitive to drought and light stress, indicating a role for this enzyme in ROS detox [117]. The largest amounts of ROS found in the mitochondria are as $\mathrm{O}_{2}{ }^{-}$molecules, which are converted in the detox process by MnSOD and APX to $\mathrm{H}_{2} \mathrm{O}_{2}$ and $\mathrm{O}_{2}$ eventually [111]. As in chloroplast, mitochondria produce ROS even in the non-stressed state at basal levels, and any form of stress causes alleviation in ROS due to ATP synthesis, leading to a reduction in the UQ pool $[18,116,118,119]$ (Figure 2).

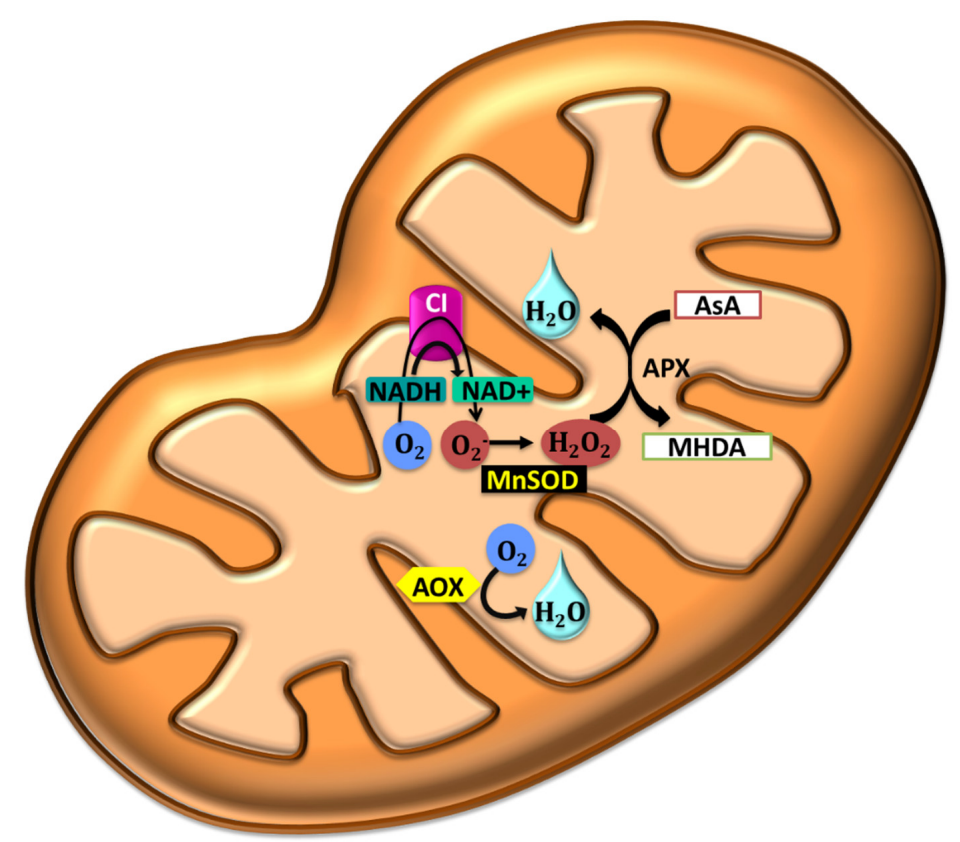

Figure 2. The process of redox in the mitochondria. Any form of stress causes alleviation in ROS due to ATP synthesis, leading to a reduction in the ubiquinone pool (UQ) pool. Several enzymes work together to manage ROS levels in mitochondria. 


\subsection{ROS Regulation at the Peroxisomes}

In drought due to reduced $\mathrm{CO}_{2}$ and $\mathrm{O}_{2}$ levels in the cell, there is an increase in the production of glycolates, which are then oxidized by glycolate oxidase in the peroxisome to $\mathrm{H}_{2} \mathrm{O}_{2}[88,120,121]$. Just as in the mitochondria and chloroplast, the peroxisome produces the $\mathrm{O}_{2}{ }^{\boldsymbol{}}{ }^{-}$even in their normal metabolism. Through a fine balance between scavenging and production, ROS levels in peroxisome are kept in check [122]. There are two sites of $\mathrm{O}^{2-}$ production in the peroxisomal matrix where xanthine oxidases convert xanthine and hypoxanthine to uric acid and $\mathrm{O}_{2}{ }^{-}$, and at the proximal membrane, $\mathrm{O}_{2}$ is used as an electron acceptor by NADH and Cytb to produce $\mathrm{O}_{2}{ }^{-}$[123]. Metabolic processes that produce $\mathrm{H}_{2} \mathrm{O}_{2}$ in the peroxisome include $\beta$-oxidation, disproportionation of radicals, and the flavin oxidase pathway $[88,124,125]$. CATs detox the system of $\mathrm{H}_{2} \mathrm{O}_{2}$ while APX and ascorbic acid (AsA)-GSH scavenge $\mathrm{H}_{2} \mathrm{O}_{2}$ in the peroxisome $[9,126,127]$. The reduced AsA-GSH contents result in lipid peroxidation of peroxisomes. Other than these enzymes, POX, a polyamine-catabolizing enzyme, has been shown to regulate stress-responsive genes to facilitate the production and scavenging of ROS in the peroxisome [128-130] (Figure 3).

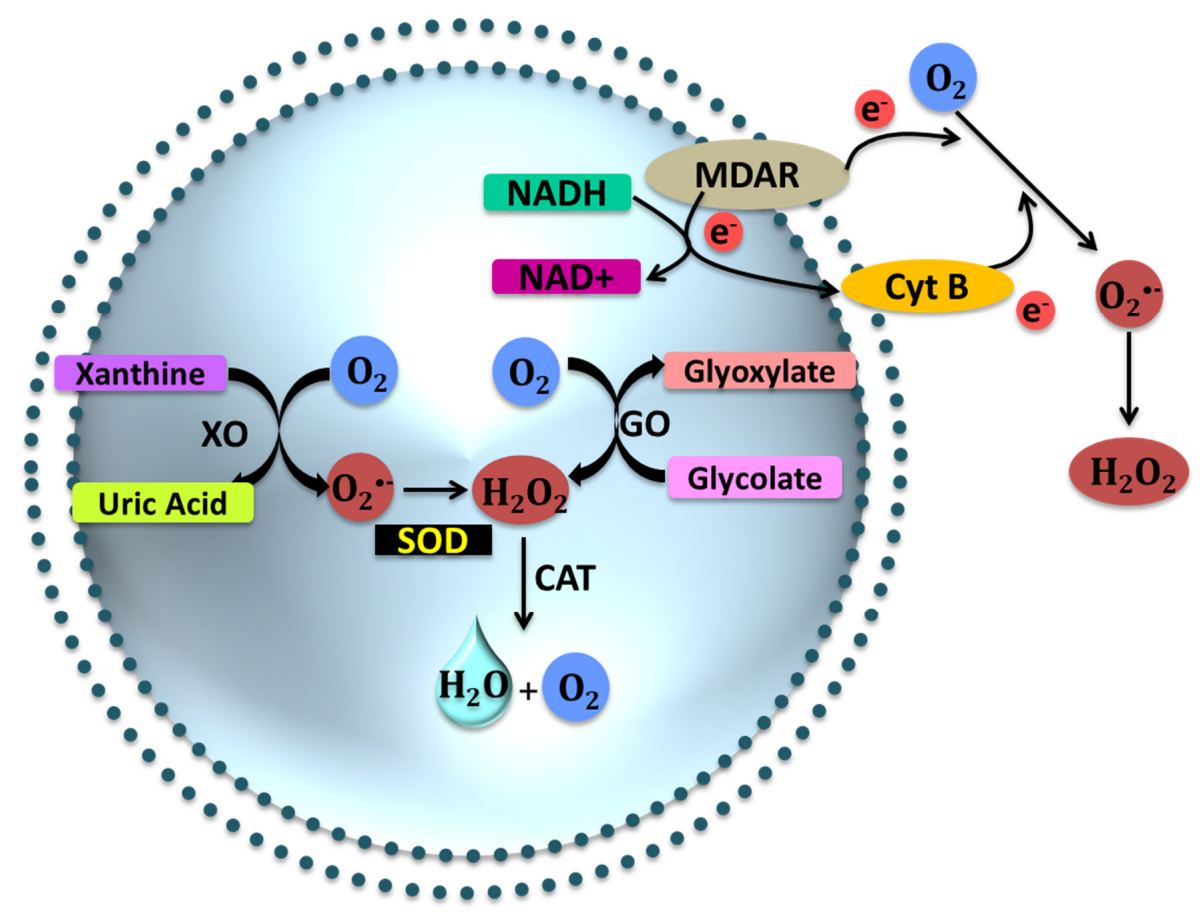

Figure 3. The process of redox in peroxisome during stress. Xanthine oxidases convert xanthine and hypoxanthine to uric acid and $\mathrm{O}_{2}{ }^{-}$, while the proximal membrane produces $\mathrm{O}_{2}{ }^{-}$via $\mathrm{NADH}$ and Cytb.

\subsection{ROS Regulation in the Apoplast}

Stress-induced ROS production is combined with the effect of ABA in the apoplast [27,131,132]. NADPH oxidases generated in the stomatal guard cells in Arabidopsis produces ROS in the apoplast as a consequence of ABA-induced stomatal closure [92,133]. AtRbohD and AtRbohF are two genes that regulate NADPH oxidases in Arabidopsis [134,135]. Other than the NADPH oxidases, peroxidases, cell wall-linked oxidases, polyamine oxidases, and oxalate oxidases play a role in generating $\mathrm{H}_{2} \mathrm{O}_{2}$ in the apoplast [136]. One important source of apoplastic ROS production is the cell wall-linked oxidases [63]. The oxalate oxidase, a cell wall germin-like protein, is known to release $\mathrm{H}_{2} \mathrm{O}_{2}$ and $\mathrm{CO}_{2}$ from oxalic acid [137]. This enzyme is mostly involved in plant defense against biotic and abiotic stress. Amine oxidases are found in the apoplast and are contributors to plant defense through the production of $\mathrm{H}_{2} \mathrm{O}_{2}$. These oxidases cause the oxidative deamination of polyamines via cofactors. As observed by Heyno et al. (2011), the hydroxyl ion generation in the apoplastic region of the cell in full or in part contributes to cell wall-bound peroxidases [138]. The increased production of $\mathrm{H}_{2} \mathrm{O}_{2}$ 
results in higher levels of polyamines and $\mathrm{Ca}^{2+}$. This results in more $\mathrm{H}_{2} \mathrm{O}_{2}$ being produced, which, in turn, activates the antioxidative machinery along with increased synthesis of higher polyamines and secondary messengers like $\mathrm{Ca}^{2+}$. ABA levels are also elevated, which leads to the activation of polyamine-activated signaling pathways in response to abiotic stresses [128] (Figure 4).

\subsection{ROS Regulation at Cell Walls and Plasma Membranes}

The cell walls of plants when stressed accumulates oxidative radicals $\mathrm{OH}^{\bullet}, \mathrm{O}_{2}{ }^{\bullet-}, \mathrm{H}_{2} \mathrm{O}_{2}$, and ${ }^{1} \mathrm{O}_{2}$. The cell walls-localized peroxidases, lipoxygenases, oxidases, and polyamines are responsible for the generation of ROS. These oxygen radicals are also responsible for the lipid peroxidation of polyunsaturated fatty acids (PUFA) found in the cell wall of plants that produce ROS [13]. The peroxidases found in the cell walls catalyze the formation of $\mathrm{H}_{2} \mathrm{O}_{2}$ through $\mathrm{NADH}$, through malate dehydrogenase. ROS generation by cell wall-associated peroxidases trigger biotic responses and the alteration of potassium [K] levels in drought-affected plants [88,111]. Liu et al. (2015), in his review, described polyamine's role in plant stress response as one that is mediated through antioxidant systems or suppression of ROS [12]. Therefore, the exogenous application of polyamines or the activation of polyamine-related genes would lead to the activation of antioxidant processes in situ in plants exposed to drought, salinity, nutrient deficiency, temperatures, and others [18,129,139].

As for the plasma membrane, NADPH oxidases localized in the membrane are responsible for generating $\mathrm{O}_{2}{ }^{\bullet-}$ through the transfer of an electron from NADPH to $\mathrm{O}_{2}$, which is then converted by SOD to $\mathrm{H}_{2} \mathrm{O}_{2}$. The NADPH oxidases in the plasma membranes are crucial players in the stress response of plant cells to environmental factors such as abiotic stresses $[18,63]$. In certain cases, multiple enzymes were found to catalyze the conversion of $\mathrm{O}_{2}$ to $\mathrm{O}_{2}{ }^{\bullet-}$. For instance, in soybean, other than NADPH oxidase, a quinone reductase also functions in the presence of menadione to facilitate the conversion of $\mathrm{O}_{2}$ to $\mathrm{O}_{2}{ }^{\bullet-}[18,63,140]$ (Figure 4).

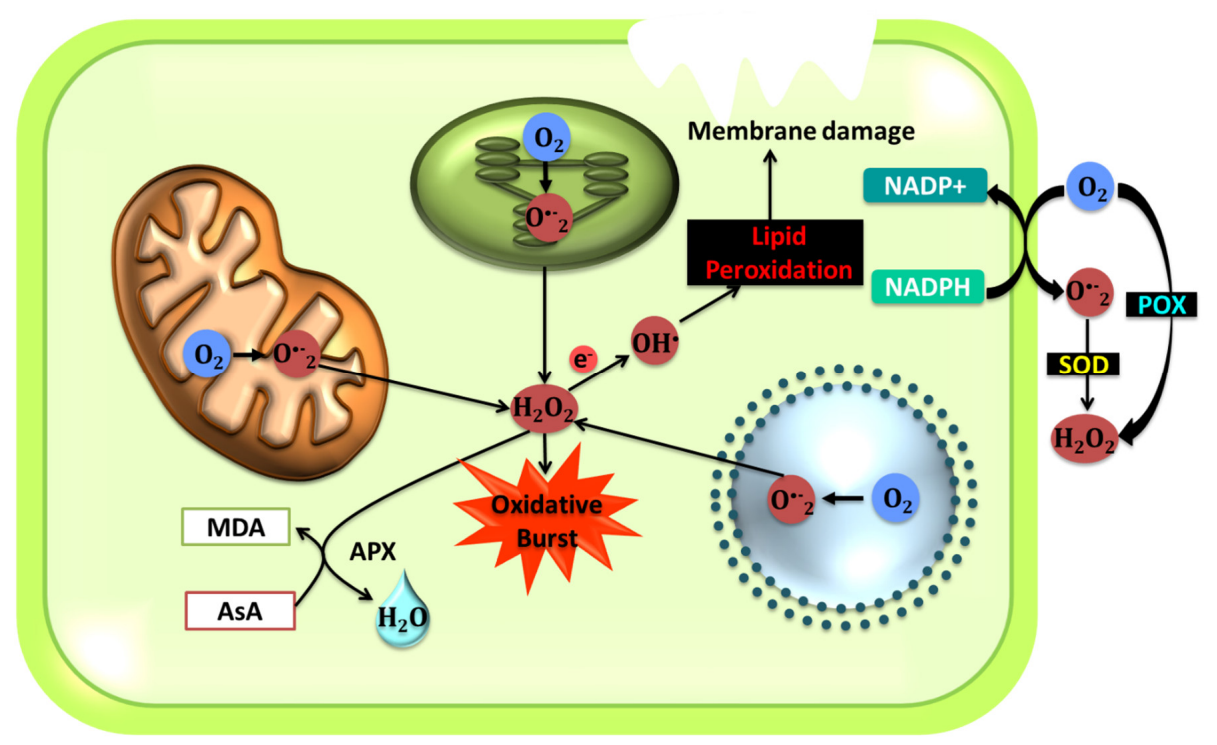

Figure 4. The processes involved in the production and control of ROS in different organelles within a plant system. The above is observed during stress response in plants. All these organelles are collectively responsible at maintaining ROS homeostasis in the cell.

\section{Genes Regulating ROS Homeostasis in Abiotic Stress}

There are an array of genes identified as key players of ROS regulation in plants [79]. Large numbers of genes are activated in response to abiotic stress in plants. These genes are highly regulated in their expression [141]. In the following section, we will briefly expound on the roles played by some of these genes, specifically genes involved in the activation and regulation of ROS in abiotic stress response [142]. 
These genes have been divided into various classes to enable a systematic illustration [143]. Table 1 and Figure 5 provide details of some of these genes and how these genes are interconnected in the regulation of abiotic stress.

Table 1. List of mitogen-activated protein (MAP) kinases and the processes they are implicated to regulate.

\begin{tabular}{|c|c|c|c|}
\hline MAP Kinase & $\begin{array}{c}\text { Phosphorylated Amino } \\
\text { Acids }\end{array}$ & List of MAP Kinases & $\begin{array}{l}\text { These MAP Kinases Respond or } \\
\text { are Involved in These Processes }\end{array}$ \\
\hline MAPKKK & Serine Threonine & $\begin{array}{l}\text { MEKK1, MEKK2, } \\
\text { MEKK3, MEKK4, } \\
\text { MAPKKK18, GhMAPKKK49 } \\
\text { DSM1, DSM2 }\end{array}$ & $\begin{array}{l}\text { Influences oxidative, abiotic, and } \\
\text { biotic stress. } \\
\text { Hormones: Abscisic acid; }\end{array}$ \\
\hline MAPKK & Threonine/tyrosine & $\begin{array}{l}\text { MKK1, MKK2, } \\
\text { MKK6, GhMKK1, } \\
\text { MKK3, GhMKK3, } \\
\text { MKK4, MKK5 GhMKK4, } \\
\text { GhMKK5, } \\
\text { MKK7, MKK8, MKK9, } \\
\text { MKK10, RhMKK9, } \\
\text { GhMKK9 ZmMKK10 }\end{array}$ & $\begin{array}{l}\text { Influences oxidative, abiotic, and } \\
\text { biotic stresses and cell division. } \\
\text { Hormones: Salicylic acid; } \\
\text { Influences oxidative, abiotic, and } \\
\text { biotic stresses and cell division. } \\
\text { Hormones: Salicylic acid; } \\
\text { Influences oxidative, abiotic, and } \\
\text { biotic stresses } \\
\text { Hormones: Jasmonic acid. } \\
\text { Influences oxidative and biotic } \\
\text { stresses, Hormones: Ethylene }\end{array}$ \\
\hline MAPK & Serine/Threonine/Tyrosine & $\begin{array}{l}\text { MPK3, MPK6, MPK10 } \\
\text { OsMPK6, ZmMPK3, RhMPK6, } \\
\text { ZmMPK6-2, OsMPK3, } \\
\text { ZmMPK3 } \\
\text { MPK4, MPK5, MPK11, MPK12, } \\
\text { MPK13 OsMPK4ZmMPK4-1, } \\
\text { OsMPK5, OsMPK5, ZmMPK5 } \\
\text { MPK1, MPK2, MPK7, } \\
\text { MPK14, ZmMPK7, } \\
\text { OsMPK2AtMPK7, } \\
\text { OsMPK7, GhMPK7 } \\
\text { MPK8, MPK9, } \\
\text { MPK15/16/17/18/19/20 } \\
\text { GhMPK17, ZmMPK17 }\end{array}$ & $\begin{array}{l}\text { Influences oxidative, abiotic, and } \\
\text { biotic stresses. } \\
\text { Hormones: Jasmonic acid } \\
\text { and ethylene } \\
\text { Influences oxidative, abiotic, and } \\
\text { biotic stresses and cell division. } \\
\text { Hormones: Salicylic acid; } \\
\text { Influences oxidative, abiotic, and } \\
\text { biotic stresses. } \\
\text { Circadian-rhythm-regulated. } \\
\text { Hormones: Jasmonic acid, } \\
\text { abscisic acid. } \\
\text { Influences oxidative, abiotic, and } \\
\text { biotic stresses. } \\
\text { Hormones: Jasmonic acid }\end{array}$ \\
\hline
\end{tabular}

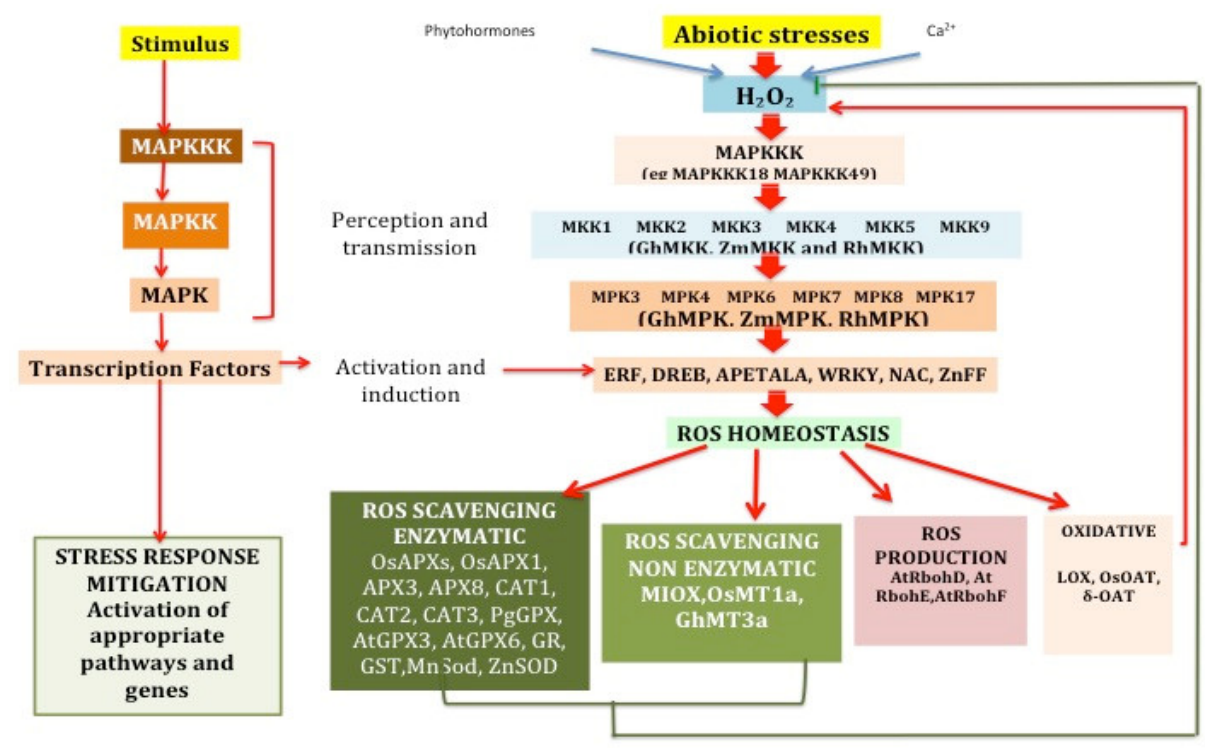

Figure 5. The pathway taken from the time of stimulus to the activation of genes downstream and the genes involved in the regulation of this pathway. 


\subsection{Protein Kinases and Phosphatases}

One of the important gene groups involved in ROS signaling is the mitogen-activated protein kinases (MAPK). There have been many MAPK cascades studied in plants [144]. This gene can be activated by different external stimuli. For instance, MPK6 in Arabidopsis is activated by abiotic stress (drought) and repressed under rehydration $[145,146]$. In roses, RhMPK6 is produced at high levels during hydration, which phosphorylates and stabilizes RhACS1, resulting in ethylene production [147]. Through signal transduction that follows, flower opening and senescence are controlled. Chen et al. (2017) also notes that RhMKK9 is involved in dehydration-dependent ethylene biosynthesis, where it works on RhMPK6-RhACS1 [148]. In another study by Mitula et al. (2015), MAPKKK18 was reported to control stomatal aperture and development [149]. Through mutant studies of this gene, it was concluded that MAPKKK18 controlled ABA-dependent stomatal closure under stress [145,150].

GhMKK1 from cotton was able to increase stress resistance and result in ROS homeostasis. Likewise, BnMKK1 (from Brassica napus), when introduced and overexpressed in transgenic tobacco, triggered ABA signaling, causing rapid water loss and drought sensitivity. This, therefore, indicates that this gene generates drought-susceptible plants [151]. GhMKK5, however, reduced tolerance to salt and other stresses [152]. In Arabidopsis, overexpression of GhMPK17 resulted in increased $\mathrm{H}_{2} \mathrm{O}_{2}$ levels and osmotic stress [145,153]. In cotton, a novel GhMAPKKK49 was induced in response to $A B A$ or $\mathrm{H}_{2} \mathrm{O}_{2}$ [142]. Further, GhMAPKKK49 was also hypothesized to interact with GhMKK4 and GhMKK9 in mediating ABA- and $\mathrm{H}_{2} \mathrm{O}_{2}$-mediated abiotic stress responses. Wang et al. (2016) reported that GhMKK3 regulates drought tolerance through control of the water deficit. GhMKK3 overexpression in tobacco effectively induced ABA-responsive stomatal closure and reduction in stomatal numbers [154,155]. Danquah et al. (2015) noted that GhMKK3 and GhPIP1 work in concert with GhMPK7 to generate drought and ABA-activated MAPK modules [156]. Transgenic tobacco overexpressing ZmMKK3-1 (ZmMKK3) from maize exhibited enhanced tolerance toward stress-induced oxidative stress [152]. ZmMKK1 is induced by ABA in maize roots and results in drought and salinity tolerance in Arabidopsis [157]. ZmMPK4-1, $\mathrm{ZmMPK7}$, and ZmMPK17 were also involved in the regulation of oxidative stress [158] where ZmMKK10 is jointly activated by $Z m M P K 7$ and $Z m M P K 3$ during drought in maize [159]. Similarly, AtMPK6, AtMPK7, OsMPK5, and OsMPK show ABA-induced defense as in ZmMPK3 and ZmMPK6-2 [152,155]. Salt Intolerance 1 (SIT1), a receptor-like kinase (RLK), is expressed at high levels in rice root cells during stress and is induced when exposed to salt stress. SIT1 activation of MPK3 and MPK6 in drought and salinity was determined via immunoprecipitation assays where both kinases were reported to form a complex with SIT1 [160], leading to the phosphorylation of MPK3 and MPK6. From the reports on various plant systems, MAPK pathways are involved in both biotic and abiotic stress modulation and act in concert with phytohormone and calcium ion signaling to activate antioxidant in plants.

Protein phosphatases are another large gene family found in plants. The sequencing project of Medicago truncatula identified and characterized PPC2 genes in the genome [161]. Further genome analysis in other plants systems such as rice, tomato, Arabidopsis, peppers, and maize indicated the presence of PP2C gene families [162-164]. These genes are responsible for the plants adaptation to environmental conditions and stresses [165]. There are two main subfamilies of PP2C that are present in plants. The subfamily A of PP2Cs are involved in stress responses that are ABA-dependent, while subfamily B phosphatases are MAPK regulators [165]. Further studies of the PP2C genes in Arabidopsis and rice indicate an active role for these genes in abiotic stresses that are ABA-dependent [163,166]. In M. truncatula, subfamily A genes were either up- or down-regulated during drought in an ABA-contingent manner. Through an in-depth study of the PP2C gene in M. truncatula, MtPP2C8, MtPP2C37, MtPP2C46, MtPP2C47, MtPP2C67, MtPP2C72, and MtPP2C73 were reported to be homologous to the HAI PP2Cs in Arabidopsis and are induced by stress. In addition, MtPP2C92 and MtPP2C65 expression were induced under stress. In Arabidopsis, the HAI PP2Cs provide drought resistance and have the greatest influence on the ABA-independent low-water-potential phenotypes compared to the classical phenotypes [166]. Further, the homologs of MtPP2C92 and 
MtPP2C65 in Arabidopsis (ABI1 and ABI2, respectively) are the most well-documented PP2C genes that are ABA-dependent and are active under abiotic stresses $[163,165]$. The MP2C (homolog with AP2C1) in alfalfa acts as a negative regulator of the MAPK pathway in cold and drought $[167,168]$. The AP2C2 (homolog MtPP2C72) regulates ROS levels in response to biotic and abiotic stresses [168]. AP2C1 is strongly induced in response to drought and cold, while AP2C2 is less responsive [164].

\subsection{Transcriptional Factors}

Transcriptional factors (TFs) play an important role in stress-responsive gene regulation and expression. ERF, DREB, APETALA, WRKY, NAC, and Zn finger families play an important role in stress regulation in plants [169-172]. Zn finger family proteins (ZFP) are important in cellular function in eukaryotes and have been divided into several classes such as $\mathrm{C} 2 \mathrm{H} 2, \mathrm{CCCH}, \mathrm{C} 2 \mathrm{HC}$, and $\mathrm{C} 2 \mathrm{C} 2$ based on the location of their $\mathrm{Zn}$ residues $[173,174]$. ZFP have been implicated as regulators of defense, development, growth, and stress in plant systems $[175,176]$. ZFPs play a key role in oxidative stress response in various plant systems [177]. ZFPs are integral in ROS defense where genes such as ZAT7, ZAT10, and ZAT12 are up-regulated in Arabidopsis knockout plants during oxidative stress [178-180]. A drought- and salt-tolerant Arabidopsis mutant, dst, encodes a C2H2-type ZFP with the ability to negatively regulate stomatal closure. This is achieved through a DST-mediated $\mathrm{H}_{2} \mathrm{O}_{2}$ regulation of increased stomatal closure and enhanced drought resistance [181]. In rice, the DST complex was reported to work in association with DST Co-activator 1 [DCA1] to regulate stomata, and aperture and downstream regulation of drought-responsive genes. This complex induces genes involved in POX production and $\mathrm{H}_{2} \mathrm{O}_{2}$ detoxification. However, overexpression of DCA1 increased sensitivity to stress [182]. In rice, the OsAHL1 gene expression improved stress tolerance through alleviation of stress at the plasma membrane [183].

ZFP36, another C2H2-type ZFP gene, is involved in antioxidant defense and enhances resistance to oxidative stress tolerance in rice $[184,185]$. This gene is a major player in the regulation of cross-talk between key players of oxidative stress such as $\mathrm{H}_{2} \mathrm{O}_{2}$, NADPH oxidase, MAPK, and ABA signaling [184]. The incorporation of the $Z F P 245(\mathrm{C} 2 \mathrm{H} 2)$ gene in rice increased abiotic stress tolerance through the activation of ROS-scavenging enzymes such as SOD and POX. ZFP179, ZFP182, and ZFP252 were also linked to the oxidative stress response via ROS signaling in rice $[27,153,186]$. A tandem ZFP, OsTZF1, negatively regulates leaf senescence under drought and oxidative stress in rice through the expression of ROS homeostasis genes and scavenging enzymes [153,187]. Similarly, GhTZF1, a TZF gene, also modulates oxidative and senescence stress in cotton through the mediation of ROS equilibrium [188].

Another TF family that has a wide involvement in rice and Arabidopsis is the WRKY family, which has over 100 WRKY genes in both plants collectively. This TF regulates both biotic and abiotic stresses [189]. The WRKY TF family is recognized by the presence of WRKYGQK heptapeptide and a zinc-finger-like motif at the $\mathrm{N}$ - and C-terminus, respectively $[190,191]$. These conserved domains play an important role in regulating important physiological processes by binding to promoter regions of target genes [161,192,193]. WRKY, in association with ROS and ABA, functions in mitigating the effects of oxidative stress in rice. OsWRKY30 and OsWRKY45 are two WRKY genes in rice that, when overexpressed, are effective at increasing drought tolerance in rice under the regulation of OsNAC6 and SNAC1 as promoters. The OsWRKY45 also plays an important role in abiotic stress in Arabidopsis [194,195]. Further, when the WRKY57 gene from Arabidopsis was transferred to rice, the transgenic rice showed reduction in water loss, electrolyte leakage, and cell death. In these interactions, OsNAC1 and SNAC1 have been implicated as the promoters controlling WRKY57 function. These plants exhibit up-regulation of stress-responsive genes with higher antioxidant and proline content [196]. In transgenic soybean, the GmWRKY27 interacts with GmMYB17 to repress promoter activity and gene expression of $G m N A C 29$, which results in reduced ROS levels and enhanced stress tolerance [197]. GmNAC29 negatively regulates stress where it enhances ROS production enzymes, leading to elevated stress. In another study, Yan et al. (2014) showed that GhWRKY17 reduced drought 
and salt tolerance in tobacco plants through mediation of cellular ROS levels and ABA signaling [198]. Further, the BdWRKY36 gene isolated from Brachypodium distachyon positively regulates abiotic stress through moderation of ROS homeostasis and regulation of stress-responsive genes [27,199].

NAC (for NAM, ATAF-1,-2, and CUC2) is one of the largest TF families with close to 300 members in just Arabidopsis and rice $[200,201]$. NACs, like the previously discussed proteins, regulate plant growth, development, oxidative stress, and drought tolerance [169,201-204]. GmNAC2, a soybean NAC, negatively regulates abiotic stress through the induction of ROS signaling and expression of stress-responsive genes [27,205-207]. The Eleusine coracana-isolated EcNAC1 gene, when transformed into tobacco, exhibited enhanced ROS scavenging and expression of abiotic stress-related genes [208,209]. Further, the SNAC3 gene in rice positively regulates stress through ROS homeostasis and enhanced ROS-associated enzyme activity $[27,210]$. A SNAC1-regulated downstream gene, OsPP18, mediates drought resistance via ROS homeostasis $[27,211]$. The mutant ospp18 was susceptible to drought and oxidative stress. As the ABA-induced expression of ABA-responsive genes was not disrupted in the ospp 18 mutant, the OsPP18 gene expression is predicted to be regulated in an ABA-independent manner [27].

Another group of transcription factors that regulate multiple abiotic stress responses are the AP2/ERF (APETALA2/ethylene response factor) families, which include DREB/CBF [212]. SUB1A, an ERF found in certain rice varieties, was able to adapt to stress and economize on energies spent in stress through ethylene and gibberellin responsiveness [213]. Following flooding and anoxic injury, plants go through severe desiccation when the water subsides. This results in ROS accumulation in plant tissues $[213,214]$ where SUB1A enhances oxidative stress tolerance through activation of ROS-scavenging genes. SUB1A is able to improve plant tolerance to abiotic stress through the induction of ABA responsiveness and activation of stress genes [214,215]. The JERF3 gene from tomato has been reported to regulate ROS activity and, therefore, reduces the osmotic and oxidative stress response in any abiotic conditions [216] by binding to cis elements in stress-responsive genes. This gene in tobacco increased abiotic stress tolerance [216].

\subsection{ROS-Scavenging and Detoxification Proteins}

Under stress, the ROS-scavenging gene families are activated in plants. Here, we present the enzymatic (processes catalyzed by enzymes) and non-enzymatic (non-enzymatic regulation) genes responsible for ROS-scavenging systems that manage the state of detoxification and homeostasis within plant cells. These genes include ascorbate peroxidase (APX), CAT, dehydroascorbate reductase (DHAR), glutathione peroxidase $(G P X)$, glutathione reductase $(G R)$, glutathione $S$-transferase (GST), monodehydroascorbate reductase (MDHAR), myo-inositol monooxygenease (MIOX), peroxiredoxin $(P R X)$, proline synthesis, and SOD. In a study conducted on transgenic rice, the $M n S O D$ gene expressed in chloroplast exhibited a fold increase in antioxidant levels, leading to enhanced stress tolerance. In plant systems, SODs are the frontline defense against ROS and are classified by the metal ions that are bound to their active sites such as copper and zinc ( $\mathrm{Cu} / \mathrm{ZnSOD})$, manganese (MnSOD), and iron (FeSOD). Different metal ions-bound SODs are found in different cellular locations. For instance, $\mathrm{Cu} / \mathrm{ZnSOD}$ are found in the cytosol and chloroplasts, while MnSOD is located in the mitochondria and peroxisomes. FeSOD is generally found in chloroplast but is significant in prokaryotes [217]. SODs protect the photosynthetic machinery against ROS in transgenic plants compared to wild type under drought-stress $[18,32,99,218]$. Similarly, the $\mathrm{Zn}$ and $\mathrm{Cu}$-containing superoxides remove oxygen radicals from plant cells. Rice transformed with $\mathrm{Zn} / \mathrm{Cu}$ SOD genes had increased abiotic stress tolerance $[62,219,220]$. Further, in transgenic alfalfa, the overexpression of MnSOD from tobacco increased the survival and yield of alfalfa over several seasons in drought conditions [221].

The APX is involved in the initial step of the AsA-GSH cycle that scavenges ROS and protects the plant from stress $[219,222]$. This haem enzyme scavenges $\mathrm{H}_{2} \mathrm{O}_{2}$ through the AsA-GSH cycle where $\mathrm{H}_{2} \mathrm{O}_{2}$ is converted to water and dehydroascorbate DHA [63,223,224]. In different abiotic stresses, APX activity is elevated [225-227]. In rice, several isoforms of the APX gene have been identified in 
the genome. Out of these isoforms, the OsAPX2 gene has been shown to protect against oxidative injury in rice seedlings [228,229]. The overexpression of OsAPX2 in transgenic rice increases APX activity and results in a reduction in $\mathrm{H}_{2} \mathrm{O}_{2}$ and malondialdehyde (MDA) under abiotic stress [229]. The reduction in $\mathrm{H}_{2} \mathrm{O}_{2}$ and malondialdehyde (MDA) is probably the reason behind the increased tolerance exhibited by transgenic rice compared to wild type in the booting stage where spikelet fertility is enhanced [229]. OsAPX1 exhibited augmented spikelet fertility under cold stress [229]. Prakash et al. (2016) reported that both the APX3 and APX8 genes are responsible for drought tolerance in IR64 and Nagina [230]. Like APX, GPX is another large family of diverse peroxidase isozymes without the haem-thiol group. This enzyme is responsible for the reduction of $\mathrm{H}_{2} \mathrm{O}_{2}$ to water, and lipid hydroperoxides to alcohol, hence repairing lipid peroxidation and membrane damage [120,231]. Both the intracellular and extracellular forms of this enzyme are involved in $\mathrm{H}_{2} \mathrm{O}_{2}$ scavenging. GPX and other peroxidase enzymes bound to plant cell walls can oxidize phenols to result in the lignification of cell walls [46]. GPX also functions as an oxidative signal transducer in plants [232]. In a functional study of the PgGPX (Pennisetum glauccum GPX) genes introduced into rice, the transgenic lines showed an enhanced antioxidant defense via lower $\mathrm{H}_{2} \mathrm{O}_{2}$ and MDA content during abiotic stresses [233].

As a haem-containing enzyme, catalase scavenges $\mathrm{H}_{2} \mathrm{O}_{2}$ in the peroxisome, glyoxysomes, and other organelles during stress-related processes [18,234]. CATs respond variably to different abiotic stresses [225,227,235-237]. It has a higher turnover rate minus the requirement for a reductant like APX, giving it a higher affinity and scavenging ability of $\mathrm{H}_{2} \mathrm{O}_{2}$. The catalase isoforms are divided into classes, which are specific to location. CAT1 and 2 are in the peroxisomes and cytosol while CAT3 is in the mitochondria [68]. GR, another oxidoreductase, regulates the GSH redox state by catalyzing the disulphide bond formation of the GSSG pool via NADPH. This is important in maintaining the GSH at a reduced state. GR is predominantly located in the chloroplast but is also reported in cytosol and mitochondria. Both GR and GSH have been identified as enzymes linked with tolerance against various stresses in plants [238-240].

MDHAR accompanies APX and scavenges $\mathrm{H}_{2} \mathrm{O}_{2}$ in the mitochondria and peroxisome $[236,237]$. MDHAR accepts electrons from NADH and, together with DHAR and GR, regulates abiotic stress in rice. DHAR works on ascorbate and recycles ascorbic acid (AsA) [241,242]. AsA is then oxidized to form MDHA, which is further converted to DHA. DHAR through GSH reduces DHA to AsA and undergoes rapid regeneration. This regeneration of AsA is moderated through the NADPH-MDHAR cycle [243], which is essential in ensuring and maintaining a reduced pool of AsA [244,245]. Maintenance of the cellular redox state of AsA is essential in abiotic stress tolerance. Increased DHAR and MDHAR activity was reported in various plants subjected to abiotic stress [99,238,246,247]. GST together with GSH can reduce POX activity in the cell through scavenging. In addition to their ability to conjugate electrophilic compounds to GSH, GST displays POX-like activities [248]. There are over 100 GST genes that have been reported in soybean, maize, and Arabidopsis [233] with diverse function, including cellular metabolism, hormone homeostasis, cellular detoxification, apoptosis, and various other biotic and abiotic stresses $[249,250]$. This enzyme is induced at high levels when plants are subject to abiotic stresses $[99,146,251,252]$.

MIOX produces AsA, which results in antioxidant defense. Oxidative damage in rice is reduced through the overexpression of OsMIOX and increased ROS scavenging $[19,253]$. Another enzyme that scavenges ROS is ornithine $\delta$-aminotransferase $(\delta$-OAT), which synthesizes proline, a non-enzymatic ROS-scavenging system effective in abiotic conditions [21,254]. You et al. (2012) reported that the overexpression of OsOAT induced enzyme activities that resulted in ROS quenching and improved antioxidative activity within the plant cells [255]. Other than proline, metallothioneins (MTs) are another low-molecular-weight protein that has metal-binding capabilities. MTs are involved in ROS detoxification and the maintenance of safe redox levels. OsMT1a expression in rice is enhanced in plants that are subjected to $\mathrm{Zn}^{2+}$ treatment and drought [256]. These plants exhibit elevated levels of APX, CAT, and POD that result in these transgenic lines exhibiting heightened tolerance to drought stress. $\mathrm{Zn}^{2+}$ homeostasis is important in improved resistance in plants. OsMT1a interacts with $\mathrm{Zn}$ 
finger transcription factors that can moderate the levels of $\mathrm{Zn}^{2+}$ within the cell. In cotton, GhMT3a resulted in an enhanced ability to bind metal ions, resulting in efficient ROS scavenging in planta. GhMT3a, when introduced into tobacco, resulted in improved resistance against multiple abiotic stresses through lower $\mathrm{H}_{2} \mathrm{O}_{2}$ levels than those exhibited in wild-type plants $[27,57,100,257]$.

In addition to the enzymatic and non-enzymatic genes that have been mentioned above, sugars are suggested to have a role in antioxidative responses. Fructans, disaccharide, and sugar alcohols possess antioxidative abilities and can efficiently remove hydroxyl radicals within plant cells and organelles $[54,258]$. This non-enzymatic removal of the ${ }^{\circ} \mathrm{OH}$ radical is important as there are not any enzymatic systems available for the removal of this toxic compound [259]. Galactinol and raffinose have demonstrated similar potential to GSH in the removal of hydroxyl ions from plant cells [260]. The levels of these sugars in chloroplast are comparable to AsA and GSH, suggesting that these sugars play a vital role in scavenging radical ions in this organelle $[111,239,261]$. However, the role of sucrose as antioxidants is only relevant in plants with high levels of sucrose such as beet and sugarcane, where they have been reported to remove ${ }^{\circ} \mathrm{OH}$ effectively [262].

\subsection{Other Proteins}

\subsection{1. $\mathrm{Ca}^{2+}$ Transporters and Binding Proteins}

Most of the $\mathrm{Ca}^{2+}$-binding sites contain the EF-hand motifs that are highly conserved amongst eukaryotes [263]. The EF-hand motifs are also found in the proteins family that transport and manage intracellular $\mathrm{Ca}^{2+}$ concentrations [264]. The influx and efflux of $\mathrm{Ca}^{2+}$ across the membranes is achieved through $\mathrm{Ca}^{2+}$ ATPases or antiporters. Both the calcium transporters and binding proteins help to regulate processes by the altering of $\mathrm{Ca}^{2+}$ levels in cells. The main players of calcium binding in plants are calmodulin [CaM], CaM-like proteins (CML), calcineurin-B-like proteins (CBL), and $\mathrm{Ca}^{2+}$ dependent protein kinases (CDPK). CaM, CML, and CBL are the sensors, while CDPK are sensor responders that activate the kinase activity of this protein [265]. As drought affects growth, development, and stress tolerance, $\mathrm{Ca}^{2+}$ is implicated in the regulation of signaling involving drought-affected processes. Calcium-binding proteins bind calcium and thence activate the downstream phosphorylation cascade of gene expression. This increases the levels of $\mathrm{Ca}^{2+}$ perceived by calmodulin and CDPK. OsACA6, a form of $\mathrm{Ca}^{2+}$ ATPase in rice, when overexpressed, is able to moderate the reduction in ROS levels. The overexpression of this gene results in cellular homeostasis through the modulation of ROS-scavenging systems [73,266].

Further, another group of proteins, annexins, are implicated in the response toward environmental stresses on growth and development. One such annexin, OsANN1, functions as an ATPase with the ability to bind $\mathrm{Ca}^{2+}$ and regulate the inflow and efflux of $\mathrm{Ca}^{2+}$ ions. Through the interaction with OsCDPK10, a protein kinase, OsANN1 confers abiotic stress tolerance via antioxidant accumulation [267]. Further, through yeast two-hybrid system analyses, it was demonstrated that OsANN1 interacts with OsCDPK24 and, therefore, regulates abiotic stress responses [268]. The RNAi knockout mutant of this gene was sensitive to drought, while the overexpressing lines showed improved growth and higher expression of the gene under abiotic stress, leading to SOD and CAT activities that facilitate ROS homeostasis through a OsANN1 and $\mathrm{H}_{2} \mathrm{O}_{2}$ feedback mechanism.

In another study involving stomatal guard cells, it was reported that cytosolic $\mathrm{Ca}^{2+}$ increase and activation of ABA results in activation of the anion channel, which causes the plasma membrane of the guard cells to close. In Arabidopsis, an ABC protein, AtMRP5 was bound to the plasma membrane of guard cells, which affects the ABA and cytosolic $\mathrm{Ca}^{2+}$ levels in the cell. Mutants of this gene showed loss of ability to keep the stomata closed in drought. These mutants also showed impaired ABA activity, indicating that this gene was responsible for $\mathrm{Ca}^{2+}$ control over guard cell aperture [269]. 


\subsubsection{SRO Proteins}

SRO is a plant-specific protein group that has the PARP, RST and WWE domain [270]. The $r c d 1$ [radical-induced cell death1] in Arabidopsis exhibited the ability to respond to various stimuli such as ROS stress, salt stress, and irradiation by interacting with numerous transcription factors that facilitate their involvement in developmental and stress-related responses $[27,271,272]$. The $R C D 1$ gene regulates signaling pathways that are responsible for quantitative changes to gene expression in response to ROS [273]. OsSRO1c is targeted by SNAC1 in rice [78], where it is induced in the guard cells during abiotic stress and results in the accumulation of $\mathrm{H}_{2} \mathrm{O}_{2}$ and decreased stomatal aperture and water loss. Due to its involvement in stomatal aperture control and water loss, the overexpression of OsSRO1c has also been implicated in abiotic stress tolerance of rice through the regulation of the SNAC1 novel pathway and DST [78]. Just like OsSRO1c, OsNAC5 and ONAC095 enhance drought and oxidative stress tolerance in rice [274]. Further studies of the SRO protein in wheat showed that this gene was also involved in the regulation of salinity stress in addition to redox homeostasis [27]. The regulation of salinity tolerance in wheat is achieved through the point mutation of the Ta-sro1 allele. The overexpression of the Ta-sro1 results in regulation of ROS through ROS-associated enzymes such as AsA-GSH and GPX that result in cellular homeostasis [27].

\subsubsection{ABA Metabolism-Related Proteins}

$\mathrm{ABA}$ is involved in the response to abiotic stresses [275]. In drought, $d s m 2$ mutants have shown impaired $\beta$-carotene hydroxylase synthesis in rice [85]. This particular hydroxylase is a precursor of ABA and is inhibited under drought stress. However, in overexpressing DSM2 lines, this gene is expressed at high levels, leading to enhanced resistance to abiotic and oxidative stress. Other than $\beta$-carotene hydroxylase, OsABA80x3 is another hydroxylase-encoding gene that is involved in ABA catabolism and regulates oxidative stress under various abiotic stresses [27]. RNAi-generated plants of this gene showed improved drought and oxidative stress tolerance with enhanced superoxide dismutase and catalase activities. In another study, transgenic tobacco carrying the 9-cis-epoxy carotenoid dioxygenase gene showed enhanced tolerance to abiotic stresses. This enhanced resistance has been linked to production of $\mathrm{H}_{2} \mathrm{O}_{2}$ that induces the expression of ROS-scavenging enzymes [276].

\section{Conclusions and Future Prospective}

Abiotic stresses hamper growth and development, which eventually results in low yields and productivity. Stressed plants exhibiting elevated intracellular and extracellular ROS are different organelles, leading to oxidative stress. Though the compartmentalization of antioxidant activities is well defined, the recognition, response, and balancing of ROS activity in the plant require further exploration. The coordination of the different enzymes in different compartments and the regulation of ROS levels in response to stress are questions that require further attention. The ambiguities and gaps in our knowledge are further compounded by the short half-life and the reactive nature of the molecule. From the various studies that have been conducted over the past two decades, we may conclude, in general, that ROS equilibrium involves cross-talk between $\mathrm{ABA}, \mathrm{Ca}^{2+}$, and various other hormones and signaling molecules. ROS as a signal transducer also activates a cascade of genes that assist in abiotic stress tolerance in a ROS-dependent manner. Genes such as protein kinases and transcription factors are important upstream components that are responsible for the activation of other downstream genes involved in alleviating ROS toxicity. Genes that are involved in the regulation of ROS have been studied quite well in rice and Arabidopsis.

In this review, we have provided an overview of the oxidative and non-oxidative mechanisms involved in the reduction in ROS damage and the provision of tolerance and adaptation to abiotic stress. We are still not completely clear on the mechanism by which $\mathrm{Ca}^{2+}$, hormones, and signal molecules regulate abiotic stresses. Perhaps with the development of better imaging systems, we may be able to utilize ion markers that provide a better understanding of their role in ROS metabolism. Further, 
genome information has been utilized in functional and metabolome studies that provide a clearer view of the ROS network and its reactions. A combination of transcriptome, proteome, and metabolome approaches may provide a comprehensive understanding of the networks involved in ROS production, signaling, and control. These studies may result in the identification of key pathways, regulators, and genes that are responsible for ROS homeostasis in plants. Some of these genes may be developed into biomarkers to be used in plant stress-response studies.

By understanding the genes and their expression, we are then able to manipulate the endogenous ROS levels to generate plants with improved defense, growth, development, and survival in adverse abiotic stress conditions. Most of the genes identified in ROS homeostasis have been characterized through the generation of transgenic plants. Some of these transgenic lines with overexpressing genes have shown enhanced tolerance to multiple stresses [277]. However, the networks involved in the function of these genes achieving ROS homeostasis requires further investigation and addition of any new and relevant information into the existing pathways. Some of these genes have already been used in elite cultivars and are candidates for biomarkers in the selection of abiotic-resistant crops. The location of these genes and QTLs associated with these genes is also a suitable candidate for use in the breeding and genetic engineering of resistant cultivars.

Funding: This work was supported by the Universiti Kebangsaan Malaysia [DCP-2017-004/1] and Ministry of Higher Education [FRGS/1/2019/STG03/UKM/01/2].

Acknowledgments: The authors would like to sincerely thank Ilakiya Kumar [https://orcid.org/0000-0002-99689156] for the technical assistance.

Conflicts of Interest: The author declares no conflict of interest. The funders had no role in the design of the study; in the collection, analyses, or interpretation of data; in the writing of the manuscript, or in the decision to publish the result.

\section{References}

1. Basu, S.; Ramegowda, V.; Kumar, A.; Pereira, A. Plant adaptation to drought stress. F1000Research 2016, 5, 1554. [CrossRef] [PubMed]

2. Lima, J.M.; Nath, M.; Dokku, P.; Raman, K.; Kulkarni, K.; Vishwakarma, C.; Sahoo, S.; Mohapatra, U.; Mithra, S.; Chinnusamy, V. Physiological, anatomical and transcriptional alterations in a rice mutant leading to enhanced water stress tolerance. AoB Plants 2015, 7. [CrossRef] [PubMed]

3. Hirayama, T.; Shinozaki, K. Research on plant abiotic stress responses in the post-genome era: Past, present and future. Plant J. 2010, 61, 1041-1052. [CrossRef]

4. Claeys, H.; Inzé, D. The agony of choice: How plants balance growth and survival under water-limiting conditions. Plant Physiol. 2013, 162, 1768-1779. [CrossRef] [PubMed]

5. Thorpe, G.W.; Reodica, M.; Davies, M.J.; Heeren, G.; Jarolim, S.; Pillay, B.; Breitenbach, M.; Higgins, V.J.; Dawes, I.W. Superoxide radicals have a protective role during $\mathrm{H}_{2} \mathrm{O}_{2}$ stress. Mol. Biol. Cell 2013, 24, 2876-2884. [CrossRef] [PubMed]

6. Nouman, W.; Basra, S.M.A.; Yasmeen, A.; Gull, T.; Hussain, S.B.; Zubair, M.; Gul, R. Seed priming improves the emergence potential, growth and antioxidant system of Moringa oleifera under saline conditions. Plant Growth Regul. 2014, 73, 267-278. [CrossRef]

7. Abbasi, A.R.; Hajirezaei, M.; Hofius, D.; Sonnewald, U.; Voll, L.M. Specific roles of $\alpha$-and $\gamma$-tocopherol in abiotic stress responses of transgenic tobacco. Plant Physiol. 2007, 143, 1720-1738. [CrossRef] [PubMed]

8. Hussain, H.A.; Hussain, S.; Khaliq, A.; Ashraf, U.; Anjum, S.A.; Men, S.; Wang, L. Chilling and drought stresses in crop plants: Implications, cross talk, and potential management opportunities. Front. Plant Sci. 2018, 9, 393. [CrossRef]

9. Mittler, R.; Vanderauwera, S.; Gollery, M.; Van Breusegem, F. Reactive oxygen gene network of plants. Trends Plant Sci. 2004, 9, 490-498. [CrossRef]

10. Beckhauser, T.F.; Francis-Oliveira, J.; De Pasquale, R. Reactive oxygen species: Physiological and physiopathological effects on synaptic plasticity: Supplementary issue: Brain plasticity and repair. J. Exp. Neurosci. 2016, 10, S39887. [CrossRef] 
11. Awasthi, R.; Bhandari, K.; Nayyar, H. Temperature stress and redox homeostasis in agricultural crops. Front. Environ. Sci. 2015, 3, 11. [CrossRef]

12. Chan, Z.; Yokawa, K.; Kim, W.Y.; Song, C.P. ROS regulation during plant abiotic stress responses. Front. Plant Sci. 2016, 7, 1536. [CrossRef] [PubMed]

13. Sewelam, N.; Kazan, K.; Schenk, P.M. Global plant stress signaling: Reactive oxygen species at the cross-road. Front. Plant Sci. 2016, 7, 187. [CrossRef] [PubMed]

14. Cheah, B.H.; Nadarajah, K.; Divate, M.D.; Wickneswari, R. Identification of four functionally important microRNA families with contrasting differential expression profiles between drought-tolerant and susceptible rice leaf at vegetative stage. BMC Genom. 2015, 16, 692. [CrossRef]

15. Miller, G.; Shulaev, V.; Mittler, R. Reactive oxygen signaling and abiotic stress. Physiol. Plant. 2008, 133, 481-489. [CrossRef] [PubMed]

16. Cheah, B.H.; Jadhao, S.; Vasudevan, M.; Wickneswari, R.; Nadarajah, K. Identification of functionally important microRNAs from rice inflorescence at heading stage of a qDTY4. 1-QTL bearing near isogenic line under drought conditions. PLOS ONE 2017, 12, e0186382. [CrossRef]

17. Kao, C.H. Mechanisms of salt tolerance in rice plants: Cell wall-related genes and expansins. J. Taiwan Agric. Res. 2017, 66, 87-93.

18. Das, K.; Roychoudhury, A. Reactive oxygen species (ROS) and response of antioxidants as ROS-scavengers during environmental stress in plants. Front. Environ. Sci. 2014, 2, 53. [CrossRef]

19. Duan, J.; Zhang, M.; Zhang, H.; Xiong, H.; Liu, P.; Ali, J.; Li, J.; Li, Z. OsMIOX, a myo-inositol oxygenase gene, improves drought tolerance through scavenging of reactive oxygen species in rice (Oryza sativa L.). Plant Sci. 2012, 196, 143-151. [CrossRef]

20. Yin, X.M.; Huang, L.F.; Zhang, X.; Wang, M.L.; Xu, G.Y.; Xia, X.J. OsCML4 improves drought tolerance through scavenging of reactive oxygen species in rice. J. Plant Biol. 2015, 58, 68-73. [CrossRef]

21. Gill, S.S.; Tuteja, N. Reactive oxygen species and antioxidant machinery in abiotic stress tolerance in crop plants. Plant Physiol. Biochem. 2010, 48, 909-930. [CrossRef]

22. Nouman, W.; Anwar, F.; Gull, T.; Newton, A.; Rosa, E.; Domínguez-Perles, R. Profiling of polyphenolics, nutrients and antioxidant potential of germplasm's leaves from seven cultivars of Moringa oleifera Lam. Ind. Crop. Prod. 2016, 83, 166-176. [CrossRef]

23. de Carvalho, K.; de Campos, M.K.F.; Domingues, D.S.; Pereira, L.F.P.; Vieira, L.G.E. The accumulation of endogenous proline induces changes in gene expression of several antioxidant enzymes in leaves of transgenic Swingle citrumelo. Mol. Biol. Rep. 2013, 40, 3269-3279. [CrossRef] [PubMed]

24. Brunner, I.; Herzog, C.; Dawes, M.A.; Arend, M.; Sperisen, C. How tree roots respond to drought. Front. Plant Sci. 2015, 6, 547. [CrossRef] [PubMed]

25. Huber, A.E.; Bauerle, T.L. Long-distance plant signaling pathways in response to multiple stressors: The gap in knowledge. J. Exp. Bot. 2016, 67, 2063-2079. [CrossRef] [PubMed]

26. Saradadevi, R.; Palta, J.A.; Siddique, K.H. ABA-mediated stomatal response in regulating water use during the development of terminal drought in wheat. Front. Plant Sci. 2017, 8, 1251. [CrossRef] [PubMed]

27. You, J.; Chan, Z. ROS regulation during abiotic stress responses in crop plants. Front. Plant Sci. 2015, 6, 1092. [CrossRef] [PubMed]

28. Noctor, G.; Mhamdi, A.; Foyer, C.H. The roles of reactive oxygen metabolism in drought: Not so cut and dried. Plant Physiol. 2014, 164, 1636-1648. [CrossRef]

29. Baxter, A.; Mittler, R.; Suzuki, N. ROS as key players in plant stress signalling. J. Exp. Bot. 2013, 65, 1229-1240. [CrossRef]

30. Mignolet-Spruyt, L.; Xu, E.; Idänheimo, N.; Hoeberichts, F.A.; Mühlenbock, P.; Brosché, M.; Van Breusegem, F.; Kangasjärvi, J. Spreading the news: Subcellular and organellar reactive oxygen species production and signalling. J. Exp. Bot. 2016, 67, 3831-3844. [CrossRef]

31. Sun, X.; Sun, M.; Jia, B.; Qin, Z.; Yang, K.; Chen, C.; Yu, Q.; Zhu, Y. A Glycine soja methionine sulfoxide reductase B5a interacts with the $\mathrm{Ca}^{2+} / \mathrm{CAM}$-binding kinase Gs CBRLK and activates ROS signaling under carbonate alkaline stress. Plant J. 2016, 86, 514-529. [CrossRef]

32. Cruz de Carvalho, M.H. Drought stress and reactive oxygen species: Production, scavenging and signaling. Plant Signal. Behav. 2008, 3, 156-165. [CrossRef] [PubMed] 
33. Kerchev, P.; Waszczak, C.; Lewandowska, A.; Willems, P.; Shapiguzov, A.; Li, Z.; Alseekh, S.; Mühlenbock, P.; Hoeberichts, F.A.; Huang, J. Lack of GLYCOLATE OXIDASE1, but not GLYCOLATE OXIDASE2, attenuates the photorespiratory phenotype of CATALASE2-deficient Arabidopsis. Plant Physiol. 2016, 171, 1704-1719. [CrossRef] [PubMed]

34. Gilroy, S.; Białasek, M.; Suzuki, N.; Górecka, M.; Devireddy, A.R.; Karpiński, S.; Mittler, R. ROS, calcium, and electric signals: Key mediators of rapid systemic signaling in plants. Plant Physiol. 2016, 171, 1606-1615. [CrossRef]

35. Xu, Z.; Jiang, Y.; Jia, B.; Zhou, G. Elevated-CO $\mathrm{CO}_{2}$ response of stomata and its dependence on environmental factors. Front. Plant Sci. 2016, 7, 657. [CrossRef] [PubMed]

36. Noctor, G. Metabolic signalling in defence and stress: The central roles of soluble redox couples. Plant Cell Environ. 2006, 29, 409-425. [CrossRef]

37. Duan, Z.Q.; Bai, L.; Zhao, Z.G.; Zhang, G.P.; Cheng, F.M.; Jiang, L.X.; Chen, K.M. Drought-stimulated activity of plasma membrane nicotinamide adenine dinucleotide phosphate oxidase and its catalytic properties in rice. J. Integr. Plant Biol. 2009, 51, 1104-1115. [CrossRef]

38. Asada, K. Production and scavenging of reactive oxygen species in chloroplasts and their functions. Plant Physiol. 2006, 141, 391-396. [CrossRef]

39. Ayala, A.; Muñoz, M.F.; Argüelles, S. Lipid peroxidation: Production, metabolism, and signaling mechanisms of malondialdehyde and 4-hydroxy-2-nonenal. Oxid. Med. Cell. Longev. 2014, 2014, 1-31. [CrossRef]

40. Nita, M.; Grzybowski, A. The role of the reactive oxygen species and oxidative stress in the pathomechanism of the age-related ocular diseases and other pathologies of the anterior and posterior eye segments in adults. Oxid. Med. Cell. Longev. 2016, 2016, 1-23. [CrossRef]

41. Abdal Dayem, A.; Hossain, M.; Lee, S.; Kim, K.; Saha, S.; Yang, G.M.; Choi, H.; Cho, S.G. The role of reactive oxygen species (ROS) in the biological activities of metallic nanoparticles. Int. J. Mol. Sci. 2017, 18, 120. [CrossRef] [PubMed]

42. Meng, X.; Wang, M.; Jiang, N.; Zhang, D.; Wang, L.; Liu, C. Regulation of both the reactive oxygen species level and antioxidant enzyme activity in drought-stressed rice organs by benzimidazolate-based SOD1 mimics. J. Agric. Food Chem. 2012, 60, 11211-11221. [CrossRef]

43. Chutipaijit, S. Changes in physiological and antioxidant activity of indica rice seedlings in response to mannitol-induced osmotic stress. Chil. J. Agric. Res. 2016, 76, 455-462. [CrossRef]

44. Mittler, R. ROS are good. Trends Plant Sci. 2017, 22, 11-19. [CrossRef]

45. Shabala, S.; Bose, J.; Fuglsang, A.T.; Pottosin, I. On a quest for stress tolerance genes: Membrane transporters in sensing and adapting to hostile soils. J. Exp. Bot. 2015, 67, 1015-1031. [CrossRef] [PubMed]

46. Sharma, P.; Jha, A.B.; Dubey, R.S. Oxidative stress and antioxidative defense systems in plants growing under abiotic stresses. In Handbook of Plant and Crop Stress; CRC Press: Informa, UK, 2016; pp. 109-158.

47. Kurutas, E.B. The importance of antioxidants which play the role in cellular response against oxidative/nitrosative stress: Current state. Nutr. J. 2015, 15, 71. [CrossRef]

48. Ford, K.L.; Cassin, A.; Bacic, A.F. Quantitative proteomic analysis of wheat cultivars with differing drought stress tolerance. Front. Plant Sci. 2011, 2, 44. [CrossRef]

49. Harb, A.; Krishnan, A.; Ambavaram, M.M.; Pereira, A. Molecular and physiological analysis of drought stress in Arabidopsis reveals early responses leading to acclimation in plant growth. Plant Physiol. 2010, 154, 1254-1271. [CrossRef]

50. Bhattacharjee, S. An inductive pulse of hydrogen peroxide pretreatment restores redox-homeostasis and oxidative membrane damage under extremes of temperature in two rice cultivars. Plant Growth Regul. 2012, 68, 395-410. [CrossRef]

51. Caverzan, A.; Piasecki, C.; Chavarria, G.; Stewart, C.N.; Vargas, L. Defenses against ROS in crops and weeds: The effects of interference and herbicides. Int. J. Mol. Sci. 2019, 20, 1086. [CrossRef] [PubMed]

52. Bhattacharjee, S. The language of reactive oxygen species signaling in plants. J. Bot. 2012, 2012, 985298. [CrossRef]

53. Couée, I.; Sulmon, C.; Gouesbet, G.; El Amrani, A. Involvement of soluble sugars in reactive oxygen species balance and responses to oxidative stress in plants. J. Exp. Bot. 2006, 57, 449-459. [CrossRef] [PubMed]

54. Keunen, E.; Peshev, D.; Vangronsveld, J.; Van Den Ende, W.; Cuypers, A. Plant sugars are crucial players in the oxidative challenge during abiotic stress: Extending the traditional concept. Plant Cell Environ. 2013, 36, 1242-1255. [CrossRef] [PubMed] 
55. Miranda, J.H.; Williams, R. Developmental influence of in vitro light quality and carbon dioxide on photochemical efficiency of PS II of strawberry leaves (Fragaria x ananassa). J. Appl. Hortic. 2007, 9, 13-16.

56. Avonce, N.; Leyman, B.; Mascorro-Gallardo, J.O.; Van Dijck, P.; Thevelein, J.M.; Iturriaga, G. The Arabidopsis trehalose-6-P synthase AtTPS1 gene is a regulator of glucose, abscisic acid, and stress signaling. Plant Physiol. 2004, 136, 3649-3659. [CrossRef]

57. Hossain, M.A.; Bhattacharjee, S.; Armin, S.M.; Qian, P.; Xin, W.; Li, H.Y.; Burritt, D.J.; Fujita, M.; Tran, L.S.P. Hydrogen peroxide priming modulates abiotic oxidative stress tolerance: Insights from ROS detoxification and scavenging. Front. Plant Sci. 2015, 6, 420. [CrossRef]

58. Liang, X.; Zhang, L.; Natarajan, S.K.; Becker, D.F. Proline mechanisms of stress survival. Antioxid. Redox Signal. 2013, 19, 998-1011. [CrossRef]

59. Sharma, S.; Villamor, J.G.; Verslues, P.E. Essential role of tissue-specific proline synthesis and catabolism in growth and redox balance at low water potential. Plant Physiol. 2011, 157, 292-304. [CrossRef]

60. Slama, I.; Abdelly, C.; Bouchereau, A.; Flowers, T.; Savoure, A. Diversity, distribution and roles of osmoprotective compounds accumulated in halophytes under abiotic stress. Ann. Bot. 2015, 115, 433-447. [CrossRef]

61. Annunziata, M.G.; Ciarmiello, L.F.; Woodrow, P.; Dell'Aversana, E.; Carillo, P. Spatial and temporal profile of glycine betaine accumulation in plants under abiotic stresses. Front. Plant Sci. 2019, 10, 230. [CrossRef]

62. Poljsak, B. Strategies for reducing or preventing the generation of oxidative stress. Oxid. Med. Cell. Longev. 2011, 2011, 1-15. [CrossRef] [PubMed]

63. Sharma, P.; Jha, A.B.; Dubey, R.S.; Pessarakli, M. Reactive oxygen species, oxidative damage, and antioxidative defense mechanism in plants under stressful conditions. J. Bot. 2012, 2012, 217037. [CrossRef]

64. Matysik, J.; Bhalu, B.; Mohanty, P. Molecular mechanisms of quenching of reactive oxygen species by proline under stress in plants. Curr. Sci. 2002, 2002, 525-532.

65. Molinari, H.B.C.; Marur, C.J.; Daros, E.; De Campos, M.K.F.; De Carvalho, J.F.R.P.; Filho, J.C.B.; Pereira, L.F.P.; Vieira, L.G.E. Evaluation of the stress-inducible production of proline in transgenic sugarcane (Saccharum spp.): Osmotic adjustment, chlorophyll fluorescence and oxidative stress. Physiol. Plant. 2007, 130, 218-229. [CrossRef]

66. Maxwell, D.P.; Wang, Y.; McIntosh, L. The alternative oxidase lowers mitochondrial reactive oxygen production in plant cells. Proc. Natl. Acad. Sci. USA 1999, 96, 8271-8276. [CrossRef]

67. Mittler, R. Oxidative stress, antioxidants and stress tolerance. Trends Plant Sci. 2002, 7, 405-410. [CrossRef]

68. Yadav, P.; Kaur, R.; Kohli, S.K.; Sirhindi, G.; Bhardwaj, R. Castasterone assisted accumulation of polyphenols and antioxidant to increase tolerance of B. juncea plants towards copper toxicity. Cogent Food Agric. 2016, 2, 1276821. [CrossRef]

69. Qi, J.; Song, C.P.; Wang, B.; Zhou, J.; Kangasjärvi, J.; Zhu, J.K.; Gong, Z. Reactive oxygen species signaling and stomatal movement in plant responses to drought stress and pathogen attack. J. Integr. Plant Biol. 2018, 60, 805-826. [CrossRef]

70. Kovtun, Y.; Chiu, W.L.; Tena, G.; Sheen, J. Functional analysis of oxidative stress-activated mitogen-activated protein kinase cascade in plants. Proc. Natl. Acad. Sci. USA 2000, 97, 2940-2945. [CrossRef]

71. Samuel, M.A.; Miles, G.P.; Ellis, B.E. Ozone treatment rapidly activates MAP kinase signalling in plants. Plant J. 2000, 22, 367-376. [CrossRef]

72. Zhang, J.; Wang, X.; Vikash, V.; Ye, Q.; Wu, D.; Liu, Y.; Dong, W. ROS and ROS-mediated cellular signaling. Oxid. Med. Cell. Longev. 2016, 2016, 1-18. [CrossRef]

73. Nadarajah, K.; Kumar, I.S. Drought response in rice: The miRNA story. Int. J. Mol. Sci. 2019, $20,3766$. [CrossRef]

74. Denancé, N.; Sánchez-Vallet, A.; Goffner, D.; Molina, A. Disease resistance or growth: The role of plant hormones in balancing immune responses and fitness costs. Front. Plant Sci. 2013, 4, 155. [CrossRef]

75. Toni, B.; Nurulhikma, M.I.; Cheng Seng, T.; Ismanizan, I.; Zamri, Z. Molecular characterization of OsCURT1A from upland rice in response to osmotic stress. Aust. J. Crop Sci. 2019, 13, 1343-1352. [CrossRef]

76. Nahar, K.; Hasanuzzaman, M.; Fujita, M. Roles of osmolytes in plant adaptation to drought and salinity. In Osmolytes and Plants Acclimation to Changing Environment: Emerging Omics Technologies; Springer: Delhi, India, 2016; pp. 37-68. 
77. Ji, K.; Wang, Y.; Sun, W.; Lou, Q.; Mei, H.; Shen, S.; Chen, H. Drought-responsive mechanisms in rice genotypes with contrasting drought tolerance during reproductive stage. J. Plant Physiol. 2012, 169, 336-344. [CrossRef] [PubMed]

78. You, J.; Zong, W.; Li, X.; Ning, J.; Hu, H.; Li, X.; Xiao, J.; Xiong, L. The SNAC1-targeted gene OsSRO1c modulates stomatal closure and oxidative stress tolerance by regulating hydrogen peroxide in rice. J. Exp. Bot. 2012, 64, 569-583. [CrossRef] [PubMed]

79. Jiang, M.; Zhang, J. Effect of abscisic acid on active oxygen species, antioxidative defence system and oxidative damage in leaves of maize seedlings. Plant Cell Physiol. 2001, 42, 1265-1273. [CrossRef] [PubMed]

80. Ye, N.; Zhu, G.; Liu, Y.; Li, Y.; Zhang, J. ABA controls $\mathrm{H}_{2} \mathrm{O}_{2}$ accumulation through the induction of OsCATB in rice leaves under water stress. Plant Cell Physiol. 2011, 52, 689-698. [CrossRef]

81. Yin, X.; Huang, L.; Wang, M.; Cui, Y.; Xia, X. OsDSR-1, a calmodulin-like gene, improves drought tolerance through scavenging of reactive oxygen species in rice (Oryza sativa L.). Mol. Breed. 2017, 37, 75. [CrossRef]

82. Guan, L.M.; Zhao, J.; Scandalios, J.G. Cis-elements and trans-factors that regulate expression of the maize Cat1 antioxidant gene in response to ABA and osmotic stress: $\mathrm{H}_{2} \mathrm{O}_{2}$ is the likely intermediary signaling molecule for the response. Plant J. 2000, 22, 87-95. [CrossRef]

83. Varshikar, D.; Tan, F.C. Salt and drought stress affects electron transport chain genes in rice. Int. J. Adv. Appl. Sci. 2017, 4, 106-110. [CrossRef]

84. Ning, J.; Li, X.; Hicks, L.M.; Xiong, L. A Raf-like MAPKKK gene DSM1 mediates drought resistance through reactive oxygen species scavenging in rice. Plant Physiol. 2010, 152, 876-890. [CrossRef]

85. Du, H.; Wang, N.; Cui, F.; Li, X.; Xiao, J.; Xiong, L. Characterization of the $\beta$-carotene hydroxylase gene DSM2 conferring drought and oxidative stress resistance by increasing xanthophylls and abscisic acid synthesis in rice. Plant Physiol. 2010, 154, 1304-1318. [CrossRef]

86. Campo, S.; Baldrich, P.; Messeguer, J.; Lalanne, E.; Coca, M.; San Segundo, B. Overexpression of a calcium-dependent protein kinase confers salt and drought tolerance in rice by preventing membrane lipid peroxidation. Plant Physiol. 2014, 165, 688-704. [CrossRef] [PubMed]

87. Ouyang, S.Q.; Liu, Y.F.; Liu, P.; Lei, G.; He, S.J.; Ma, B.; Zhang, W.K.; Zhang, J.S.; Chen, S.Y. Receptor-like kinase OsSIK1 improves drought and salt stress tolerance in rice (Oryza sativa) plants. Plant J. 2010, 62, 316-329. [CrossRef] [PubMed]

88. Janků, M.; Luhová, L.; Petřivalský, M. On the origin and fate of reactive oxygen species in plant cell compartments. Antioxidants 2019, 8, 105. [CrossRef]

89. Du, B.; Zhao, W.; An, Y.-M.; Li, Y.; Zhang, X.; Song, L.; Guo, C. Overexpression of an alfalfa glutathione S-transferase gene improved the saline-alkali tolerance of transgenic tobacco. Boil. Open 2019, 8, bio043505. [CrossRef]

90. Sierla, M.; Waszczak, C.; Vahisalu, T.; Kangasjärvi, J. Reactive Oxygen Species in the Regulation of Stomatal Movements. Plant Physiol. 2016, 171, 1569-1580. [CrossRef] [PubMed]

91. Acharya, B.R.; Jeon, B.W.; Zhang, W.; Assmann, S.M. Open Stomata 1 (OST 1) is limiting in abscisic acid responses of Arabidopsis guard cells. New Phytol. 2013, 200, 1049-1063. [CrossRef]

92. Rajab, H.; Khan, M.S.; Malagoli, M.; Hell, R.; Wirtz, M. Sulfate-induced stomata closure requires the canonical ABA signal transduction machinery. Plants 2019, 8, 21. [CrossRef]

93. Miao, Y.; Lv, D.; Wang, P.; Wang, X.C.; Chen, J.; Miao, C.; Song, C.P. An Arabidopsis glutathione peroxidase functions as both a redox transducer and a scavenger in abscisic acid and drought stress responses. Plant Cell 2006, 18, 2749-2766. [CrossRef] [PubMed]

94. Hayat, S.; Hayat, Q.; Alyemeni, M.N.; Wani, A.S.; Pichtel, J.; Ahmad, A. Role of proline under changing environments: A review. Plant Signal. Behav. 2012, 7, 1456-1466. [CrossRef] [PubMed]

95. Zhang, L.; Becker, D. Connecting proline metabolism and signaling pathways in plant senescence. Front. Plant Sci. 2015, 6, 552. [CrossRef] [PubMed]

96. Lee, K.P.; Kim, C.; Landgraf, F.; Apel, K. EXECUTER1- and EXECUTER2-dependent transfer of stress-related signals from the plastid to the nucleus of Arabidopsis thaliana. Proc. Natl. Acad. Sci. USA 2007, 104, 10270-10275. [CrossRef]

97. Elstner, E. Oxygen radicals-Biochemical basis for their efficacy. Klin. Wochenschr. 1991, 69, 949-956. [CrossRef]

98. Miller, G.; Suzuki, N.; Ciftci-Yilmaz, S.; Mittler, R. Reactive oxygen species homeostasis and signalling during drought and salinity stresses. Plant Cell Environ. 2010, 33, 453-467. [CrossRef] 
99. Laxa, M.; Liebthal, M.; Telman, W.; Chibani, K.; Dietz, K.J. The role of the plant antioxidant system in drought tolerance. Antioxidants 2019, 8, 94. [CrossRef] [PubMed]

100. Xie, J.; Yao, S.; Ming, J.; Deng, L.; Zeng, K. Variations in chlorophyll and carotenoid contents and expression of genes involved in pigment metabolism response to oleocellosis in citrus fruits. Food Chem. 2019, 272, $49-57$. [CrossRef]

101. Møller, I.M.; Jensen, P.E.; Hansson, A. Oxidative modifications to cellular components in plants. Annu. Rev. Plant Biol. 2007, 58, 459-481. [CrossRef]

102. Karuppanapandian, T.; Moon, J.C.; Kim, C.; Manoharan, K.; Kim, W. Reactive oxygen species in plants: Their generation, signal transduction, and scavenging mechanisms. Aust. J. Crop Sci. 2011, 5, 709.

103. Khorobrykh, S.A.; Karonen, M.; Tyystjärvi, E. Experimental evidence suggesting that $\mathrm{H}_{2} \mathrm{O}_{2}$ is produced within the thylakoid membrane in a reaction between plastoquinol and singlet oxygen. FEBS Lett. 2015, 589, 779-786. [CrossRef]

104. Ledford, H.K.; Niyogi, K.K. Singlet oxygen and photo-oxidative stress management in plants and algae. Plant Cell Environ. 2005, 28, 1037-1045. [CrossRef]

105. Atkin, O.K.; Macherel, D. The crucial role of plant mitochondria in orchestrating drought tolerance. Ann. Bot. 2008, 103, 581-597. [CrossRef]

106. Miwa, S.; Jow, H.; Baty, K.; Johnson, A.; Czapiewski, R.; Saretzki, G.; Treumann, A.; Von Zglinicki, T. Low abundance of the matrix arm of complex I in mitochondria predicts longevity in mice. Nat. Commun. 2014, 5, 3837. [CrossRef] [PubMed]

107. Chen, X.; Cheng, J.; Chen, L.; Zhang, G.; Huang, H.; Zhang, Y.; Xu, L. Auxin-independent NAC pathway acts in response to explant-specific wounding and promotes root tip emergence during de novo root organogenesis in Arabidopsis. Plant Physiol. 2016, 170, 2136-2145. [CrossRef]

108. Liu, B.; Chen, Y.; Clair, D.K.S. ROS and p53: A versatile partnership. Free Radic. Biol. Med. 2008, 44, 1529-1535. [CrossRef]

109. Sarewicz, M.; Osyczka, A. Electronic connection between the quinone and cytochrome $C$ redox pools and its role in regulation of mitochondrial electron transport and redox signaling. Physiol. Rev. 2015, 95, 219-243. [CrossRef] [PubMed]

110. Mailloux, R.J. Mitochondrial antioxidants and the maintenance of cellular hydrogen peroxide levels. Oxid. Med. Cell. Longev. 2018, 2018, 1-10. [CrossRef]

111. Sharma, V.; Anderson, D.; Dhawan, A. Zinc oxide nanoparticles induce oxidative DNA damage and ROS-triggered mitochondria mediated apoptosis in human liver cells (HepG2). Apoptosis 2012, 17, 852-870. [CrossRef]

112. Zorov, D.B.; Juhaszova, M.; Sollott, S.J. Mitochondrial reactive oxygen species (ROS) and ROS-induced ROS release. Physiol. Rev. 2014, 94, 909-950. [CrossRef]

113. Scialò, F.; Fernández-Ayala, D.J.; Sanz, A. Role of mitochondrial reverse electron transport in ROS signaling: Potential roles in health and disease. Front. Physiol. 2017, 8, 428. [CrossRef] [PubMed]

114. Rasmusson, A.G.; Geisler, D.A.; Møller, I.M. The multiplicity of dehydrogenases in the electron transport chain of plant mitochondria. Mitochondrion 2008, 8, 47-60. [CrossRef] [PubMed]

115. Rhoads, D.M.; Umbach, A.L.; Subbaiah, C.C.; Siedow, J.N. Mitochondrial reactive oxygen species. Contribution to oxidative stress and interorganellar signaling. Plant Physiol. 2006, 141, 357-366. [CrossRef] [PubMed]

116. Blokhina, O.; Fagerstedt, K.V. Reactive oxygen species and nitric oxide in plant mitochondria: Origin and redundant regulatory systems. Physiol. Plant. 2010, 138, 447-462. [CrossRef]

117. Giraud, E.; Ho, L.H.; Clifton, R.; Carroll, A.; Estavillo, G.; Tan, Y.F.; Howell, K.A.; Ivanova, A.; Pogson, B.J.; Millar, A.H. The absence of ALTERNATIVE OXIDASE1a in Arabidopsis results in acute sensitivity to combined light and drought stress. Plant Physiol. 2008, 147, 595-610. [CrossRef]

118. Mattos, L.; Moretti, C. Oxidative stress in plants under drought conditions and the role of different enzymes. Enzym. Eng. 2015, 5, 1-6. [CrossRef]

119. Fahad, S.; Bajwa, A.A.; Nazir, U.; Anjum, S.A.; Farooq, A.; Zohaib, A.; Sadia, S.; Nasim, W.; Adkins, S.; Saud, S. Crop production under drought and heat stress: Plant responses and management options. Front. Plant Sci. 2017, 8, 1147. [CrossRef]

120. Noctor, G.; Gomez, L.; Vanacker, H.; Foyer, C.H. Interactions between biosynthesis, compartmentation and transport in the control of glutathione homeostasis and signalling. J. Exp. Bot. 2002, 53, 1283-1304. [CrossRef] 
121. Karpinski, S.; Gabrys, H.; Mateo, A.; Karpinska, B.; Mullineaux, P.M. Light perception in plant disease defence signalling. Curr. Opin. Plant Biol. 2003, 6, 390-396. [CrossRef]

122. Palma, J.M.; Corpas, F.J.; del Río, L.A. Proteome of plant peroxisomes: New perspectives on the role of these organelles in cell biology. Proteomics 2009, 9, 2301-2312. [CrossRef]

123. Kostić, D.A.; Dimitrijević, D.S.; Stojanović, G.S.; Palić, I.R.; Đorđević, A.S.; Ickovski, J.D. Xanthine oxidase: Isolation, assays of activity, and inhibition. J. Chem. 2015, 2015, 1-8. [CrossRef]

124. Schrader, M.; Fahimi, H.D. Peroxisomes and oxidative stress. Biochim. Biophys. Acta (BBA) Mol. Cell Res. 2006, 1763, 1755-1766. [CrossRef] [PubMed]

125. Corpas, F.J.; Barroso, J.B.; Palma, J.M.; Rodriguez-Ruiz, M. Plant peroxisomes: A nitro-oxidative cocktail. Redox Biol. 2017, 11, 535-542. [CrossRef]

126. Jimenez, A.; Hernandez, J.A.; del Río, L.A.; Sevilla, F. Evidence for the presence of the ascorbate-glutathione cycle in mitochondria and peroxisomes of pea leaves. Plant Physiol. 1997, 114, 275-284. [CrossRef] [PubMed]

127. Vandenabeele, S.; Vanderauwera, S.; Vuylsteke, M.; Rombauts, S.; Langebartels, C.; Seidlitz, H.K.; Zabeau, M.; Van Montagu, M.; Inzé, D.; Van Breusegem, F. Catalase deficiency drastically affects gene expression induced by high light in Arabidopsis thaliana. Plant J. 2004, 39, 45-58. [CrossRef]

128. Gupta, K.; Sengupta, A.; Chakraborty, M.; Gupta, B. Hydrogen peroxide and polyamines act as double edged swords in plant abiotic stress responses. Front. Plant Sci. 2016, 7, 1343. [CrossRef]

129. Podgórska, A.; Burian, M.; Szal, B. Extra-cellular but extra-ordinarily important for cells: Apoplastic reactive oxygen species metabolism. Front. Plant Sci. 2017, 8, 1353. [CrossRef]

130. Gupta, D.K.; Palma, J.M.; Corpas, F.J. Reactive Oxygen Species and Oxidative Damage in Plants under Stress; Springer: New York, NY, USA, 2015.

131. Tripathy, B.C.; Oelmüller, R. Reactive oxygen species generation and signaling in plants. Plant Signal. Behav. 2012, 7, 1621-1633. [CrossRef]

132. Choudhury, F.K.; Rivero, R.M.; Blumwald, E.; Mittler, R. Reactive oxygen species, abiotic stress and stress combination. Plant J. 2017, 90, 856-867. [CrossRef]

133. Máthé, C.; Garda, T.; Freytag, C. The Role of Serine-threonine protein phosphatase PP2A in plant oxidative stress signaling-Facts and hypotheses. Int. J. Mol. Sci. 2019, 20, 3028. [CrossRef]

134. Kwak, J.M.; Mori, I.C.; Pei, Z.M.; Leonhardt, N.; Torres, M.A.; Dangl, J.L.; Bloom, R.E.; Bodde, S.; Jones, J.D.; Schroeder, J.I. NADPH oxidase AtrbohD and AtrbohF genes function in ROS-dependent ABA signaling in Arabidopsis. EMBO J. 2003, 22, 2623-2633. [CrossRef]

135. Torres, M.A.; Dangl, J.L. Functions of the respiratory burst oxidase in biotic interactions, abiotic stress and development. Curr. Opin. Plant Biol. 2005, 8, 397-403. [CrossRef] [PubMed]

136. Li, Y.; Xiang, J.; Wang, Y.; Zheng, L.; Fan, Y.; Li, Y.; Zhao, F. Analysis of antioxidant characteristics and related gene expression profiles of rice drought-tolerance lines derived from embryo-soaking with alternanthera philoxeroides DNA solution. J. Bot. Sci. 2015, 4, 30-36.

137. Rietz, S.; Bernsdorff, F.E.; Cai, D. Members of the germin-like protein family in Brassica napus are candidates for the initiation of an oxidative burst that impedes pathogenesis of Sclerotinia sclerotiorum. J. Exp. Bot. 2012, 63, 5507-5519. [CrossRef] [PubMed]

138. Heyno, E.; Mary, V.; Schopfer, P.; Krieger-Liszkay, A. Oxygen activation at the plasma membrane: Relation between superoxide and hydroxyl radical production by isolated membranes. Planta 2011, 234, 35-45. [CrossRef] [PubMed]

139. Liu, J.H.; Wang, W.; Wu, H.; Gong, X.; Moriguchi, T. Polyamines function in stress tolerance: From synthesis to regulation. Front. Plant Sci. 2015, 6, 827. [CrossRef]

140. Cuypers, A.; Hendrix, S.; Amaral dos Reis, R.; De Smet, S.; Deckers, J.; Gielen, H.; Jozefczak, M.; Loix, C.; Vercampt, H.; Vangronsveld, J. Hydrogen peroxide, signaling in disguise during metal phytotoxicity. Front. Plant Sci. 2016, 7, 470. [CrossRef]

141. Gahlaut, V.; Jaiswal, V.; Kumar, A.; Gupta, P.K. Transcription factors involved in drought tolerance and their possible role in developing drought tolerant cultivars with emphasis on wheat (Triticum aestivum L.). Appl. Genet. 2016, 129, 2019-2042. [CrossRef]

142. Amorim, L.L.B.; Bezerra-Neto, J.P.; do Santos, R.d.F.; Neto, J.R.C.F.; Kido, E.A.; Matos, M.; Benko-Iseppon, A.M. Transcription factors involved in plant drought tolerance regulation. In Drought Stress Tolerance in Plants; Springer: New York, NY, USA, 2016; Volume 2, pp. 315-358. 
143. Hu, H.; Xiong, L. Genetic engineering and breeding of drought-resistant crops. Annu. Rev. Plant Biol. 2014, 65, 715-741. [CrossRef]

144. Nadarajah, K.; Sidek, H.M. The green MAPKS. Asian J. Plant Sci. 2010, 9, 1. [CrossRef]

145. Jagodzik, P.; Tajdel-Zielińska, M.; Cieśla, A.; Marczak, M.; Ludwikow, A. Mitogen-activated protein kinase cascades in plant hormone signaling. Front. Plant Sci. 2018, 9, 1387. [CrossRef]

146. Wang, Y.; Branicky, R.; Noë, A.; Hekimi, S. Superoxide dismutases: Dual roles in controlling ROS damage and regulating ROS signaling. J. Cell Biol. 2018, 217, 1915-1928. [CrossRef] [PubMed]

147. Meng, Y.; Ma, N.; Zhang, Q.; You, Q.; Li, N.; Ali Khan, M.; Liu, X.; Wu, L.; Su, Z.; Gao, J. Precise spatio-temporal modulation of ACC synthase by MPK 6 cascade mediates the response of rose flowers to rehydration. Plant J. 2014, 79, 941-950. [CrossRef] [PubMed]

148. Chen, J.; Zhang, Q.; Wang, Q.; Feng, M.; Li, Y.; Meng, Y.; Zhang, Y.; Liu, G.; Ma, Z.; Wu, H. RhMKK9, a rose MAP KINASE KINASE gene, is involved in rehydration-triggered ethylene production in rose gynoecia. BMC Plant Biol. 2017, 17, 51. [CrossRef]

149. Mitula, F.; Tajdel, M.; Cieśla, A.; Kasprowicz-Maluśki, A.; Kulik, A.; Babula-Skowrońska, D.; Michalak, M.; Dobrowolska, G.; Sadowski, J.; Ludwików, A. Arabidopsis ABA-activated kinase MAPKKK18 is regulated by protein phosphatase 2C ABI1 and the ubiquitin-proteasome pathway. Plant Cell Physiol. 2015, 56, 2351-2367. [CrossRef] [PubMed]

150. Li, K.; Yang, F.; Zhang, G.; Song, S.; Li, Y.; Ren, D.; Miao, Y.; Song, C.P. AIK1, a mitogen-activated protein kinase, modulates abscisic acid responses through the MKK5-MPK6 kinase cascade. Plant Physiol. 2017, 173, 1391-1408. [CrossRef]

151. Yu, S.; Zhang, L.; Chen, C.; Li, J.; Ye, S.; Liu, G.; Mei, X.; Tang, K.; Luo, L. Isolation and characterization of BnMKK1 responsive to multiple stresses and affecting plant architecture in tobacco. Acta Physiol. Plant. 2014, 36, 1313-1324. [CrossRef]

152. Zhang, L.; Li, Y.; Lu, W.; Meng, F.; Wu, C.A.; Guo, X. Cotton GhMKK5 affects disease resistance, induces HR-like cell death, and reduces the tolerance to salt and drought stress in transgenic Nicotiana benthamiana. J. Exp. Bot. 2012, 63, 3935-3951. [CrossRef]

153. Zhang, J.; Zou, D.; Li, Y.; Sun, X.; Wang, N.N.; Gong, S.Y.; Zheng, Y.; Li, X.B. GhMPK17, a cotton mitogen-activated protein kinase, is involved in plant response to high salinity and osmotic stresses and ABA signaling. PLoS ONE 2014, 9, e95642. [CrossRef]

154. Wang, C.; Lu, W.; He, X.; Wang, F.; Zhou, Y.; Guo, X.; Guo, X. The cotton mitogen-activated protein kinase kinase 3 functions in drought tolerance by regulating stomatal responses and root growth. Plant Cell Physiol. 2016, 57, 1629-1642. [CrossRef]

155. Li, F.; Li, M.; Wang, P.; Cox, K.L., Jr.; Duan, L.; Dever, J.K.; Shan, L.; Li, Z.; He, P. Regulation of cotton (Gossypium hirsutum) drought responses by mitogen-activated protein (MAP) kinase cascade-mediated phosphorylation of Gh WRKY 59. New Phytol. 2017, 215, 1462-1475. [CrossRef]

156. Danquah, A.; de Zélicourt, A.; Boudsocq, M.; Neubauer, J.; Frei dit Frey, N.; Leonhardt, N.; Pateyron, S.; Gwinner, F.; Tamby, J.P.; Ortiz-Masia, D. Identification and characterization of an ABA-activated MAP kinase cascade in Arabidopsis thaliana. Plant J. 2015, 82, 232-244. [CrossRef] [PubMed]

157. Cai, G.; Wang, G.; Wang, L.; Liu, Y.; Pan, J.; Li, D. A maize mitogen-activated protein kinase kinase, ZmMKK1, positively regulated the salt and drought tolerance in transgenic Arabidopsis. J. Plant Physiol. 2014, 171, 1003-1016. [CrossRef] [PubMed]

158. Wang, L.; Su, H.; Han, L.; Wang, C.; Sun, Y.; Liu, F. Differential expression profiles of poplar MAP kinase kinases in response to abiotic stresses and plant hormones, and overexpression of PtMKK4 improves the drought tolerance of poplar. Gene 2014, 545, 141-148. [CrossRef]

159. Chang, Y.; Yang, H.; Ren, D.; Li, Y. Activation of ZmMKK10, a maize mitogen-activated protein kinase kinase, induces ethylene-dependent cell death. Plant Sci. 2017, 264, 129-137. [CrossRef] [PubMed]

160. Li, C.H.; Wang, G.; Zhao, J.L.; Zhang, L.Q.; Ai, L.F.; Han, Y.F.; Sun, D.Y.; Zhang, S.W.; Sun, Y. The receptor-like kinase SIT1 mediates salt sensitivity by activating MAPK3/6 and regulating ethylene homeostasis in rice. Plant Cell 2014, 26, 2538-2553. [CrossRef]

161. Yang, X.; Li, H.; Yang, Y.; Wang, Y.; Mo, Y.; Zhang, R.; Zhang, Y.; Ma, J.; Wei, C.; Zhang, X. Identification and expression analyses of WRKY genes reveal their involvement in growth and abiotic stress response in watermelon (Citrullus lanatus). PLoS ONE 2018, 13, e0191308. [CrossRef] 
162. Xue, T.; Wang, D.; Zhang, S.; Ehlting, J.; Ni, F.; Jakab, S.; Zheng, C.; Zhong, Y. Genome-wide and expression analysis of protein phosphatase $2 \mathrm{C}$ in rice and Arabidopsis. BMC Genom. 2008, 9, 550. [CrossRef] [PubMed]

163. Singh, A.; Giri, J.; Kapoor, S.; Tyagi, A.K.; Pandey, G.K. Protein phosphatase complement in rice: Genome-wide identification and transcriptional analysis under abiotic stress conditions and reproductive development. BMC Genom. 2010, 11, 435. [CrossRef]

164. Khan, N.; Ke, H.; Hu, C.M.; Naseri, E.; Haider, M.S.; Ayaz, A.; Amjad Khan, W.; Wang, J.; Hou, X. Genome-Wide Identification, Evolution, and Transcriptional Profiling of PP2C Gene Family in Brassica rapa. BioMed Res. Int. 2019, 2019, 1-15.

165. Fuchs, S.; Grill, E.; Meskiene, I.; Schweighofer, A. Type 2C protein phosphatases in plants. FEBS J. 2013, 280, 681-693. [CrossRef] [PubMed]

166. Bhaskara, G.B.; Nguyen, T.T.; Verslues, P.E. Unique drought resistance functions of the highly ABA-induced clade A protein phosphatase 2Cs. Plant Physiol. 2012, 160, 379-395. [CrossRef] [PubMed]

167. Meskiene, I.; Ligterink, W.; Bögre, L.; Jonak, C.; Kiegerl, S.; Balog, J.; Eklöf, S.; Ammerer, G.; Hirt, H. The SAM kinase pathway: An integrated circuit for stress signaling in plants. J. Plant Res. 1998, 111, 339-344. [CrossRef]

168. Yang, Q.; Liu, K.; Niu, X.; Wang, Q.; Wan, Y.; Yang, F.; Li, G.; Wang, Y.; Wang, R. Genome-wide identification of PP2C genes and their expression profiling in response to drought and cold stresses in Medicago truncatula. Sci. Rep. 2018, 8, 12841. [CrossRef]

169. Joshi, R.; Wani, S.H.; Singh, B.; Bohra, A.; Dar, Z.A.; Lone, A.A.; Pareek, A.; Singla-Pareek, S.L. Transcription factors and plants response to drought stress: Current understanding and future directions. Front. Plant Sci. 2016, 7, 1029. [CrossRef] [PubMed]

170. Wang, F.; Wang, C.; Liu, P.; Lei, C.; Hao, W.; Gao, Y.; Liu, Y.G.; Zhao, K. Enhanced rice blast resistance by CRISPR/Cas9-targeted mutagenesis of the ERF transcription factor gene OsERF922. PLoS ONE 2016, 11, e0154027. [CrossRef] [PubMed]

171. Kimotho, R.N.; Baillo, E.H.; Zhang, Z. Transcription factors involved in abiotic stress responses in Maize (Zea mays L.) and their roles in enhanced productivity in the post genomics era. PeerJ 2019, 7, e7211. [CrossRef]

172. Nadarajah, K.; Omar, N.S.; Thing, T.Y. Molecular characterization of a WRKY gene from Oryza sativa indica cultivar UKMRC9. Plant Omics 2014, 7, 63.

173. Englbrecht, C.C.; Schoof, H.; Böhm, S. Conservation, diversification and expansion of C2H2 zinc finger proteins in the Arabidopsis thaliana genome. BMC Genom. 2004, 5, 39. [CrossRef]

174. Ciftci-Yilmaz, S.; Mittler, R. The zinc finger network of plants. Cell. Mol. Life Sci. 2008, 65, 1150-1160. [CrossRef]

175. Huang, J.; Sun, S.J.; Xu, D.Q.; Yang, X.; Bao, Y.M.; Wang, Z.F.; Tang, H.J.; Zhang, H. Increased tolerance of rice to cold, drought and oxidative stresses mediated by the overexpression of a gene that encodes the zinc finger protein ZFP245. Biochem. Biophys. Res. Commun. 2009, 389, 556-561. [CrossRef] [PubMed]

176. Wang, L.; Pei, Z.; Tian, Y.; He, C. OsLSD1, a rice zinc finger protein, regulates programmed cell death and callus differentiation. Mol. Plant-Microbe Interact. 2005, 18, 375-384. [CrossRef]

177. He, L.; Ma, X.; Li, Z.; Jiao, Z.; Li, Y.; Ow, D.W. Maize OXIDATIVE STRESS2 homologs enhance cadmium tolerance in Arabidopsis through activation of a putative SAM-dependent methyltransferase gene. Plant Physiol. 2016, 171, 1675-1685. [CrossRef] [PubMed]

178. Mittler, R.; Kim, Y.; Song, L.; Coutu, J.; Coutu, A.; Ciftci-Yilmaz, S.; Lee, H.; Stevenson, B.; Zhu, J.K. Gain-and loss-of-function mutations in Zat10 enhance the tolerance of plants to abiotic stress. FEBS Lett. 2006, 580, 6537-6542. [CrossRef]

179. Xie, Y.; Mao, Y.; Lai, D.; Zhang, W.; Shen, W. H2 enhances Arabidopsis salt tolerance by manipulating ZAT10/12-mediated antioxidant defence and controlling sodium exclusion. PLoS ONE 2012, 7, e49800. [CrossRef] [PubMed]

180. Shi, H.; Chan, Z. The cysteine2/histidine2-type transcription factor zinc finger of Arabidopsis thaliana 6-activated C-REPEAT-BINDING FACTOR pathway is essential for melatonin-mediated freezing stress resistance in Arabidopsis. J. Pineal Res. 2014, 57, 185-191. [CrossRef]

181. Huang, X.Y.; Chao, D.Y.; Gao, J.P.; Zhu, M.Z.; Shi, M.; Lin, H.X. A previously unknown zinc finger protein, DST, regulates drought and salt tolerance in rice via stomatal aperture control. Genes Dev. 2009, 23, 1805-1817. [CrossRef] 
182. Cui, L.G.; Shan, J.X.; Shi, M.; Gao, J.P.; Lin, H.X. DCA1 acts as a transcriptional co-activator of DST and contributes to drought and salt tolerance in rice. PLoS Genet. 2015, 11, e1005617. [CrossRef]

183. Zhou, L.; Liu, Z.; Liu, Y.; Kong, D.; Li, T.; Yu, S.; Mei, H.; Xu, X.; Liu, H.; Chen, L. A novel gene OsAHL1 improves both drought avoidance and drought tolerance in rice. Sci. Rep. 2016, 6, 30264. [CrossRef]

184. Zhang, H.; Liu, Y.; Wen, F.; Yao, D.; Wang, L.; Guo, J.; Ni, L.; Zhang, A.; Tan, M.; Jiang, M. A novel rice $\mathrm{C}_{2} \mathrm{H}_{2}$-type zinc finger protein, ZFP36, is a key player involved in abscisic acid-induced antioxidant defence and oxidative stress tolerance in rice. J. Exp. Bot. 2014, 65, 5795-5809. [CrossRef]

185. Zhang, X.; Zhang, B.; Li, M.J.; Yin, X.M.; Huang, L.F.; Cui, Y.C.; Wang, M.L.; Xia, X. OsMSR15 encoding a rice $\mathrm{C}_{2} \mathrm{H}_{2}$-type zinc finger protein confers enhanced drought tolerance in transgenic Arabidopsis. J. Plant Biol. 2016, 59, 271-281. [CrossRef]

186. Schmidt, R.; Mieulet, D.; Hubberten, H.M.; Obata, T.; Hoefgen, R.; Fernie, A.R.; Fisahn, J.; San Segundo, B.; Guiderdoni, E.; Schippers, J.H. SALT-RESPONSIVE ERF1 regulates reactive oxygen species-dependent signaling during the initial response to salt stress in rice. Plant Cell 2013, 25, 2115-2131. [CrossRef] [PubMed]

187. Jan, A.; Maruyama, K.; Todaka, D.; Kidokoro, S.; Abo, M.; Yoshimura, E.; Shinozaki, K.; Nakashima, K.; Yamaguchi-Shinozaki, K. OsTZF1, a CCCH-tandem zinc finger protein, confers delayed senescence and stress tolerance in rice by regulating stress-related genes. Plant Physiol. 2013, 161, 1202-1216. [CrossRef] [PubMed]

188. Zhou, T.; Yang, X.; Wang, L.; Xu, J.; Zhang, X. GhTZF1 regulates drought stress responses and delays leaf senescence by inhibiting reactive oxygen species accumulation in transgenic Arabidopsis. Plant Mol. Biol. 2014, 85, 163-177. [CrossRef] [PubMed]

189. Wu, K.L.; Guo, Z.J.; Wang, H.H.; Li, J. The WRKY family of transcription factors in rice and Arabidopsis and their origins. DNA Res. 2005, 12, 9-26. [CrossRef] [PubMed]

190. Eulgem, T.; Rushton, P.J.; Robatzek, S.; Somssich, I.E. The WRKY superfamily of plant transcription factors. Trends Plant Sci. 2000, 5, 199-206. [CrossRef]

191. Imran, Q.M.; Hussain, A.; Mun, B.G.; Lee, S.U.; Asaf, S.; Ali, M.A.; Lee, I.J.; Yun, B.W. Transcriptome wide identification and characterization of NO-responsive WRKY transcription factors in Arabidopsis thaliana L. Environ. Exp. Bot. 2018, 148, 128-143. [CrossRef]

192. Mohanta, T.K.; Park, Y.H.; Bae, H. Novel genomic and evolutionary insight of WRKY transcription factors in plant lineage. Sci. Rep. 2016, 6, 37309. [CrossRef]

193. Ning, P.; Liu, C.; Kang, J.; Lv, J. Genome-wide analysis of WRKY transcription factors in wheat (Triticum aestivum L.) and differential expression under water deficit condition. PeerJ 2017, 5, e3232. [CrossRef]

194. Tao, Z.; Kou, Y.; Liu, H.; Li, X.; Xiao, J.; Wang, S. OsWRKY45 alleles play different roles in abscisic acid signalling and salt stress tolerance but similar roles in drought and cold tolerance in rice. J. Exp. Bot. 2011, 62, 4863-4874. [CrossRef]

195. Qiu, Y.; Yu, D. Over-expression of the stress-induced OsWRKY45 enhances disease resistance and drought tolerance in Arabidopsis. Environ. Exp. Bot. 2009, 65, 35-47. [CrossRef]

196. Jiang, Y.; Yu, D. The WRKY57 transcription factor affects the expression of jasmonate ZIM-domain genes transcriptionally to compromise Botrytis cinerea resistance. Plant Physiol. 2016, 171, 2771-2782. [PubMed]

197. Wang, F.; Chen, H.W.; Li, Q.T.; Wei, W.; Li, W.; Zhang, W.K.; Ma, B.; Bi, Y.D.; Lai, Y.C.; Liu, X.L. Gm WRKY 27 interacts with Gm MYB 174 to reduce expression of Gm NAC 29 for stress tolerance in soybean plants. Plant J. 2015, 83, 224-236. [CrossRef] [PubMed]

198. Yan, Y.; Jia, H.; Wang, F.; Wang, C.; Liu, S.; Guo, X. Overexpression of GhWRKY27a reduces tolerance to drought stress and resistance to Rhizoctonia solani infection in transgenic Nicotiana benthamiana. Front. Physiol. 2015, 6, 265. [CrossRef] [PubMed]

199. Sun, J.; Hu, W.; Zhou, R.; Wang, L.; Wang, X.; Wang, Q.; Feng, Z.; Li, Y.; Qiu, D.; He, G. The Brachypodium distachyon BdWRKY36 gene confers tolerance to drought stress in transgenic tobacco plants. Plant Cell Rep. 2015, 34, 23-35. [CrossRef]

200. Riechmann, J.L.; Ratcliffe, O.J. A genomic perspective on plant transcription factors. Curr. Opin. Plant Biol. 2000, 3, 423-434. [CrossRef]

201. Nuruzzaman, M.; Manimekalai, R.; Sharoni, A.M.; Satoh, K.; Kondoh, H.; Ooka, H.; Kikuchi, S. Genome-wide analysis of NAC transcription factor family in rice. Gene 2010, 465, 30-44. [CrossRef] 
202. Zhu, Y.; Yan, J.; Liu, W.; Liu, L.; Sheng, Y.; Sun, Y.; Li, Y.; Scheller, H.V.; Jiang, M.; Hou, X. Phosphorylation of a NAC transcription factor by a calcium/calmodulin-dependent protein kinase regulates abscisic acid-induced antioxidant defense in maize. Plant Physiol. 2016, 171, 1651-1664. [CrossRef]

203. Thirumalaikumar, V.P.; Devkar, V.; Mehterov, N.; Ali, S.; Ozgur, R.; Turkan, I.; Mueller-Roeber, B.; Balazadeh, S. NAC transcription factor JUNGBRUNNEN 1 enhances drought tolerance in tomato. Plant Biotechnol. J. 2018, 16, 354-366. [CrossRef]

204. Sukiran, N.L.; Ma, J.C.; Ma, H.; Su, Z. ANAC019 is required for recovery of reproductive development under drought stress in Arabidopsis. Plant Mol. Biol. 2019, 99, 161-174. [CrossRef]

205. Jin, H.; Huang, F.; Cheng, H.; Song, H.; Yu, D. Overexpression of the GmNAC2 gene, an NAC transcription factor, reduces abiotic stress tolerance in tobacco. Plant Mol. Biol. Rep. 2013, 31, 435-442. [CrossRef]

206. Pimenta, M.R.; Silva, P.A.; Mendes, G.C.; Alves, J.R.; Caetano, H.D.N.; Machado, J.P.B.; Brustolini, O.J.B.; Carpinetti, P.A.; Melo, B.P.; Silva, J.C.F. The stress-induced soybean NAC transcription factor GmNAC81 plays a positive role in developmentally programmed leaf senescence. Plant Cell Physiol. 2016, 57, 1098-1114. [CrossRef] [PubMed]

207. Guan, H.; Liu, X.; Niu, F.; Zhao, Q.; Fan, N.; Cao, D.; Meng, D.; He, W.; Guo, B.; Wei, Y. OsNAC72, a NAC-Type Oxytropis ochrocephala transcription factor, conferring enhanced drought and salt stress tolerance in Arabidopsis. Front. Plant Sci. 2019, 10, 890. [CrossRef] [PubMed]

208. Ramegowda, V.; Senthil-Kumar, M.; Nataraja, K.N.; Reddy, M.K.; Mysore, K.S.; Udayakumar, M. Expression of a finger millet transcription factor, EcNAC1, in tobacco confers abiotic stress-tolerance. PLoS ONE 2012, 7, e40397. [CrossRef] [PubMed]

209. Babitha, K.; Vemanna, R.S.; Nataraja, K.N.; Udayakumar, M. Overexpression of EcbHLH57 transcription factor from Eleusine coracana L. in tobacco confers tolerance to salt, oxidative and drought stress. PLoS ONE 2015, 10, e0137098. [CrossRef] [PubMed]

210. Fang, Y.; Liao, K.; Du, H.; Xu, Y.; Song, H.; Li, X.; Xiong, L. A stress-responsive NAC transcription factor SNAC3 confers heat and drought tolerance through modulation of reactive oxygen species in rice. J. Exp. Bot. 2015, 66, 6803-6817. [CrossRef]

211. You, J.; Zong, W.; Hu, H.; Li, X.; Xiao, J.; Xiong, L. A SNAC1-regulated protein phosphatase gene OsPP18 modulates drought and oxidative stress tolerance through ABA-independent reactive oxygen species scavenging in rice. Plant Physiol. 2014, 114, 251116.

212. Mizoi, J.; Shinozaki, K.; Yamaguchi-Shinozaki, K. AP2/ERF family transcription factors in plant abiotic stress responses. Biochim. Biophys. Acta (BBA) Gene Regul. Mech. 2012, 1819, 86-96. [CrossRef]

213. Fukao, T.; Xiong, L. Genetic mechanisms conferring adaptation to submergence and drought in rice: Simple or complex? Curr. Opin. Plant Biol. 2013, 16, 196-204. [CrossRef]

214. Fukao, T.; Yeung, E.; Bailey-Serres, J. The submergence tolerance regulator SUB1A mediates crosstalk between submergence and drought tolerance in rice. Plant Cell 2011, 23, 412-427. [CrossRef]

215. Yeung, E.; van Veen, H.; Vashisht, D.; Paiva, A.L.S.; Hummel, M.; Rankenberg, T.; Steffens, B.; Steffen-Heins, A.; Sauter, M.; de Vries, M. A stress recovery signaling network for enhanced flooding tolerance in Arabidopsis thaliana. Proc. Natl. Acad. Sci. USA 2018, 115, E6085-E6094. [CrossRef] [PubMed]

216. Wu, L.; Zhang, Z.; Zhang, H.; Wang, X.C.; Huang, R. Transcriptional modulation of ethylene response factor protein JERF3 in the oxidative stress response enhances tolerance of tobacco seedlings to salt, drought, and freezing. Plant Physiol. 2008, 148, 1953-1963. [CrossRef] [PubMed]

217. Miller, A.F. Superoxide dismutases: Ancient enzymes and new insights. FEBS Lett. 2012, 586, 585-595. [CrossRef] [PubMed]

218. Molina-Rueda, J.J.; Tsai, C.J.; Kirby, E.G. The Populus superoxide dismutase gene family and its responses to drought stress in transgenic poplar overexpressing a pine cytosolic glutamine synthetase (GS1a). PLoS ONE 2013, 8, e56421. [CrossRef]

219. Prashanth, S.; Sadhasivam, V.; Parida, A. Over expression of cytosolic copper/zinc superoxide dismutase from a mangrove plant Avicennia marina in indica rice var Pusa Basmati-1 confers abiotic stress tolerance. Transgenic Res. 2008, 17, 281-291. [CrossRef]

220. Luis, A.; Corpas, F.J.; López-Huertas, E.; Palma, J.M. Plant superoxide dismutases: Function under abiotic stress conditions. In Antioxidants and Antioxidant Enzymes in Higher Plants; Springer: New York, NY, USA, 2018; pp. 1-26. 
221. McKersie, B.D.; Bowley, S.R.; Harjanto, E.; Leprince, O. Water-deficit tolerance and field performance of transgenic alfalfa overexpressing superoxide dismutase. Plant Physiol. 1996, 111, 1177-1181. [CrossRef]

222. Asada, K. Production and action of active oxygen species in photosynthetic tissues. In Causes of Photooxidative Stress and Amelioration of Defense Systems in Plants; CRC Press: Boca Raton, FL, USA, 1994; pp. 77-104.

223. Pandey, P.; Singh, J.; Achary, V.; Reddy, M.K. Redox homeostasis via gene families of ascorbate-glutathione pathway. Front. Environ. Sci. 2015, 3, 25. [CrossRef]

224. Akram, N.A.; Shafiq, F.; Ashraf, M. Ascorbic acid-a potential oxidant scavenger and its role in plant development and abiotic stress tolerance. Front. Plant Sci. 2017, 8, 613. [CrossRef]

225. Singh, S.; Khan, N.A.; Nazar, R.; Anjum, N.A. Photosynthetic traits and activities of antioxidant enzymes in blackgram (Vigna mungo L. Hepper) under cadmium stress. Am. J. Plant Physiol. 2008, 3, 25-32.

226. Caverzan, A.; Passaia, G.; Rosa, S.B.; Ribeiro, C.W.; Lazzarotto, F.; Margis-Pinheiro, M. Plant responses to stresses: Role of ascorbate peroxidase in the antioxidant protection. Genet. Mol. Biol. 2012, 35, 1011-1019. [CrossRef]

227. Pandey, S.; Fartyal, D.; Agarwal, A.; Shukla, T.; James, D.; Kaul, T.; Negi, Y.K.; Arora, S.; Reddy, M.K. Abiotic stress tolerance in plants: Myriad roles of ascorbate peroxidase. Front. Plant Sci. 2017, 8, 581. [CrossRef] [PubMed]

228. Teixeira, F.K.; Menezes-Benavente, L.; Galvão, V.C.; Margis, R.; Margis-Pinheiro, M. Rice ascorbate peroxidase gene family encodes functionally diverse isoforms localized in different subcellular compartments. Planta 2006, 224, 300. [CrossRef] [PubMed]

229. Zhang, Z.; Zhang, Q.; Wu, J.; Zheng, X.; Zheng, S.; Sun, X.; Qiu, Q.; Lu, T. Gene knockout study reveals that cytosolic ascorbate peroxidase 2 (OsAPX2) plays a critical role in growth and reproduction in rice under drought, salt and cold stresses. PLoS ONE 2013, 8, e57472. [CrossRef] [PubMed]

230. Prakash, C.; Mithra, S.A.; Singh, P.K.; Mohapatra, T.; Singh, N. Unraveling the molecular basis of oxidative stress management in a drought tolerant rice genotype Nagina 22. BMC Genom. 2016, 17, 774. [CrossRef] [PubMed]

231. Kühn, H.; Borchert, A. Regulation of enzymatic lipid peroxidation: The interplay of peroxidizing and peroxide reducing enzymes. Free Radic. Biol. Med. 2002, 33, 154-172. [CrossRef]

232. Sofo, A.; Scopa, A.; Nuzzaci, M.; Vitti, A. Ascorbate peroxidase and catalase activities and their genetic regulation in plants subjected to drought and salinity stresses. Int. J. Mol. Sci. 2015, 16, 13561-13578. [CrossRef]

233. Islam, T.; Manna, M.; Reddy, M.K. Glutathione peroxidase of Pennisetum glaucum (PgGPx) is a functional $\mathrm{Cd}^{2+}$ dependent peroxiredoxin that enhances tolerance against salinity and drought stress. PLoS ONE 2015, 10, e0143344. [CrossRef]

234. Sandalio, L.; Romero-Puertas, M. Peroxisomes sense and respond to environmental cues by regulating ROS and RNS signalling networks. Ann. Bot. 2015, 116, 475-485. [CrossRef]

235. Scandalios, J. Oxidative stress: Molecular perception and transduction of signals triggering antioxidant gene defenses. Braz. J. Med Biol. Res. 2005, 38, 995-1014. [CrossRef]

236. Hasanuzzaman, M.; Hossain, M.A.; Fujita, M. Nitric oxide modulates antioxidant defense and the methylglyoxal detoxification system and reduces salinity-induced damage of wheat seedlings. Plant Biotechnol. Rep. 2011, 5, 353. [CrossRef]

237. Hasanuzzaman, M.; Fujita, M. Selenium pretreatment upregulates the antioxidant defense and methylglyoxal detoxification system and confers enhanced tolerance to drought stress in rapeseed seedlings. Biol. Trace Elem. Res. 2011, 143, 1758-1776. [CrossRef] [PubMed]

238. Hasanuzzaman, M.; Hossain, M.A.; da Silva, J.A.T.; Fujita, M. Plant response and tolerance to abiotic oxidative stress: Antioxidant defense is a key factor. In Crop Stress and Its Management: Perspectives and Strategies; Springer: Berlin, Germany, 2012; pp. 261-315.

239. Yadav, N.; Sharma, S. Reactive oxygen species, oxidative stress and ROS scavenging system in plants. J. Chem. Pharm. Res. 2016, 8, 595-604.

240. Demarquoy, J.; Le Borgne, F. Crosstalk between mitochondria and peroxisomes. World J. Biol. Chem. 2015, 6, 301. [CrossRef]

241. Gallie, D.R. The role of L-ascorbic acid recycling in responding to environmental stress and in promoting plant growth. J. Exp. Bot. 2012, 64, 433-443. [CrossRef] [PubMed] 
242. Venkatesh, J.; Park, S.W. Role of L-ascorbate in alleviating abiotic stresses in crop plants. Bot. Stud. 2014, 55, 38. [CrossRef]

243. Mittova, V.; Volokita, M.; Guy, M.; Tal, M. Activities of SOD and the ascorbate-glutathione cycle enzymes in subcellular compartments in leaves and roots of the cultivated tomato and its wild salt-tolerant relative Lycopersicon pennellii. Physiol. Plant. 2000, 110, 42-51. [CrossRef]

244. Martínez, J.P.; Araya, H. Ascorbate-glutathione cycle: Enzymatic and non-enzymatic integrated mechanisms and its biomolecular regulation. In Ascorbate-Glutathione Pathway and Stress Tolerance in Plants; Springer: New York, NY, USA, 2010; pp. 303-322.

245. Hossain, M.S.; Dietz, K.J. Tuning of redox regulatory mechanisms, reactive oxygen species and redox homeostasis under salinity stress. Front. Plant Sci. 2016, 7, 548. [CrossRef]

246. Hossain, M.A.; Hasanuzzaman, M.; Fujita, M. Up-regulation of antioxidant and glyoxalase systems by exogenous glycinebetaine and proline in mung bean confer tolerance to cadmium stress. Physiol. Mol. Biol. Plants 2010, 16, 259-272. [CrossRef]

247. Sharma, A.; Zheng, B. Melatonin mediated regulation of drought stress: Physiological and molecular aspects. Plants 2019, 8, 190. [CrossRef] [PubMed]

248. Gullner, G.; Komives, T.; Király, L.; Schröder, P. Glutathione S-transferase enzymes in plant-pathogen interactions. Front. Plant Sci. 2018, 9. [CrossRef] [PubMed]

249. Petrov, V.; Hille, J.; Mueller-Roeber, B.; Gechev, T.S. ROS-mediated abiotic stress-induced programmed cell death in plants. Front. Plant Sci. 2015, 6, 69. [CrossRef] [PubMed]

250. Wang, L.; Ding, L.; Yu, Z.; Zhang, T.; Ma, S.; Liu, J. Intracellular ROS scavenging and antioxidant enzyme regulating capacities of corn gluten meal-derived antioxidant peptides in HepG2 cells. Food Res. Int. 2016, 90, 33-41. [CrossRef] [PubMed]

251. Sharma, P.; Dubey, R.S. Drought induces oxidative stress and enhances the activities of antioxidant enzymes in growing rice seedlings. Plant Growth Regul. 2005, 46, 209-221. [CrossRef]

252. Anjum, S.A.; Ashraf, U.; Tanveer, M.; Khan, I.; Hussain, S.; Shahzad, B.; Zohaib, A.; Abbas, F.; Saleem, M.F.; Ali, I.; et al. Drought Induced Changes in Growth, Osmolyte Accumulation and Antioxidant Metabolism of Three Maize Hybrids. Front. Plant Sci. 2017, 8, 19. [CrossRef] [PubMed]

253. Shao, H.B.; Chu, L.Y.; Shao, M.A.; Jaleel, C.A.; Hong-Mei, M. Higher plant antioxidants and redox signaling under environmental stresses. C. R. Biol. 2008, 331, 433-441. [CrossRef]

254. Stránská, J.; Kopečný, D.; Tylichová, M.; Snégaroff, J.; Šebela, M. Ornithine $\delta$-aminotransferase: An enzyme implicated in salt tolerance in higher plants. Plant Signal. Behav. 2008, 3, 929-935. [CrossRef]

255. You, J.; Hu, H.; Xiong, L. An ornithine $\delta$-aminotransferase gene OsOAT confers drought and oxidative stress tolerance in rice. Plant Sci. 2012, 197, 59-69. [CrossRef]

256. Yang, Z.; Wu, Y.; Li, Y.; Ling, H.Q.; Chu, C. OsMT1a, a type 1 metallothionein, plays the pivotal role in zinc homeostasis and drought tolerance in rice. Plant Mol. Biol. 2009, 70, 219-229. [CrossRef]

257. Xue, Y.; Gu, X.; Wang, X.; Sun, C.; Xu, X.; Sun, J.; Zhang, B. The hydroxyl radical generation and oxidative stress for the earthworm Eisenia fetida exposed to tetrabromobisphenol A. Ecotoxicology 2009, 18, 693-699. [CrossRef]

258. Peshev, D.; Vergauwen, R.; Moglia, A.; Hideg, É.; Van den Ende, W. Towards understanding vacuolar antioxidant mechanisms: A role for fructans? J. Exp. Bot. 2013, 64, 1025-1038. [CrossRef]

259. Gechev, T.S.; Van Breusegem, F.; Stone, J.M.; Denev, I.; Laloi, C. Reactive oxygen species as signals that modulate plant stress responses and programmed cell death. Bioessays 2006, 28, 1091-1101. [CrossRef] [PubMed]

260. Nishizawa, A.; Yabuta, Y.; Shigeoka, S. Galactinol and raffinose constitute a novel function to protect plants from oxidative damage. Plant Physiol. 2008, 147, 1251-1263. [CrossRef] [PubMed]

261. Stoyanova, S.; Geuns, J.; Hideg, E.; Van Den Ende, W. The food additives inulin and stevioside counteract oxidative stress. Int. J. Food Sci. Nutr. 2011, 62, 207-214. [CrossRef] [PubMed]

262. Van den Ende, W.; Valluru, R. Sucrose, sucrosyl oligosaccharides, and oxidative stress: Scavenging and salvaging? J. Exp. Bot. 2008, 60, 9-18. [CrossRef] [PubMed]

263. Gifford, J.L.; Walsh, M.P.; Vogel, H.J. Structures and metal-ion-binding properties of the Ca ${ }^{2+}$-binding helix-loop-helix EF-hand motifs. Biochem. J. 2007, 405, 199-221. [CrossRef]

264. Schwaller, B. Cytosolic $\mathrm{Ca}^{2+}$ buffers. Cold Spring Harb. Perspect. Biol. 2010, 2, a004051. [CrossRef] 
265. DeFalco, T.A.; Bender, K.W.; Snedden, W.A. Breaking the code: $\mathrm{Ca}^{2+}$ sensors in plant signalling. Biochem. J. 2010, 425, 27-40. [CrossRef]

266. Huda, K.M.; Banu, M.S.A.; Garg, B.; Tula, S.; Tuteja, R.; Tuteja, N. Os ACA 6, a P-type IIB Ca ${ }^{2+}$ ATP ase promotes salinity and drought stress tolerance in tobacco by ROS scavenging and enhancing the expression of stress-responsive genes. Plant J. 2013, 76, 997-1015. [CrossRef]

267. Bundó, M.; Coca, M. Calcium-dependent protein kinase OsCPK10 mediates both drought tolerance and blast disease resistance in rice plants. J. Exp. Bot. 2017, 68, 2963-2975. [CrossRef]

268. Qiao, B.; Zhang, Q.; Liu, D.; Wang, H.; Yin, J.; Wang, R.; He, M.; Cui, M.; Shang, Z.; Wang, D. A calcium-binding protein, rice annexin OsANN1, enhances heat stress tolerance by modulating the production of $\mathrm{H}_{2} \mathrm{O}_{2}$. J. Exp. Bot. 2015, 66, 5853-5866. [CrossRef]

269. Daszkowska-Golec, A.; Szarejko, I. Open or close the gate-Stomata action under the control of phytohormones in drought stress conditions. Front. Plant Sci. 2013, 4, 138. [CrossRef] [PubMed]

270. Jaspers, P.; Overmyer, K.; Wrzaczek, M.; Vainonen, J.P.; Blomster, T.; Salojärvi, J.; Reddy, R.A.; Kangasjärvi, J. The RST and PARP-like domain containing SRO protein family: Analysis of protein structure, function and conservation in land plants. BMC Genom. 2010, 11, 170. [CrossRef] [PubMed]

271. Ahlfors, R.; Lång, S.; Overmyer, K.; Jaspers, P.; Brosché, M.; Tauriainen, A.; Kollist, H.; Tuominen, H.; Belles-Boix, E.; Piippo, M. Arabidopsis RADICAL-INDUCED CELL DEATH1 belongs to the WWE protein-protein interaction domain protein family and modulates abscisic acid, ethylene, and methyl jasmonate responses. Plant Cell 2004, 16, 1925-1937. [CrossRef] [PubMed]

272. Wrzaczek, M.; Vainonen, J.P.; Gauthier, A.; Overmyer, K.; Kangasjärvi, J. Reactive oxygen in abiotic stress perception-from genes to proteins. In Abiotic Stress Response Plants; Shanker, A., Venkateswarlu, B., Eds.; Intech: Rijeka, Croatia, 2011; pp. 27-55.

273. Shapiguzov, A.; Vainonen, J.P.; Hunter, K.; Tossavainen, H.; Tiwari, A.; Jarvi, S.; Hellman, M.; Aarabi, F.; Alseekh, S.; Wybouw, B.; et al. Arabidopsis RCD1 coordinates chloroplast and mitochondrial functions through interaction with ANAC transcription factors. Elife 2019, 8, 8. [CrossRef]

274. Huang, S.; Van Aken, O.; Schwarzländer, M.; Belt, K.; Millar, A.H. The roles of mitochondrial reactive oxygen species in cellular signaling and stress response in plants. Plant Physiol. 2016, 171, 1551-1559. [CrossRef]

275. Hamid, N.A.A.; Zainal, Z.; Ismail, I. Two members of unassigned type of short-chain dehydrogenase/reductase superfamily (SDR) isolated from Persicaria minor show response towards ABA and drought stress. J. Plant Biochem. Biotechnol. 2018, 27, 260-271. [CrossRef]

276. Liang, D. A Salutary Role of reactive oxygen species in intercellular tunnel-mediated communication. Front. Cell Dev. Biol. 2018, 6, 2. [CrossRef]

277. Huang, H.; Ullah, F.; Zhou, D.X.; Yi, M.; Zhao, Y. Mechanisms of ROS regulation of plant development and stress responses. Front. Plant Sci. 2019, 10, 800. [CrossRef] 